\title{
An Exploratory Analysis of Vegetation Strategies to Reduce Shallow Landslide Activity on Loess Hillslopes, Northeast Qinghai-Tibet Plateau, China
}

\author{
HU Xia-song1,2, BRIERLEY Gary3* ${ }^{*}$ ZHU Hai-li' ${ }^{1}$, LI Guo-rong1, FU Jiang-tao², MAO Xiao-qing1, \\ YU Qin-qin', QIAO Na1 \\ 1 Department of Geological Engineering, Qinghai University, Xining, Qinghai, 81oo16, China \\ 2 Qinghai Institute of Salt Lakes, Chinese Academy of Sciences, Xining, Qinghai, 810oo8, China \\ 3 School of Environment, University of Auckland, Private Bag 92019, Auckland City 1142, New Zealand \\ *Corresponding author, e-mail: g.brierley@auckland.ac.nz; First author, e-mail: huxiasong@sina.com
}

(C) Science Press and Institute of Mountain Hazards and Environment, CAS and Springer-Verlag Berlin Heidelberg 2013

\begin{abstract}
Heavy summer rainfall induces significant soil erosion and shallow landslide activity on the loess hillslopes of the Xining Basin at the northeast margin of the Qinghai-Tibet Plateau. This study examines the mechanical effects of five native shrubs that can be used to reduce shallow landslide activity. We measured single root tensile resistance and shear resistance, root anatomical structure and direct shear and triaxial shear for soil without roots and five rootsoil composite systems. Results show that Atriplex canescens (Pursh) Nutt. possessed the strongest roots, followed by Caragana korshinskii Kom., Zygophyllum xanthoxylon (Bunge) Maxim., Nitraria tangutorum Bobr. and Lycium chinense Mill. Single root strength and shear resistance relationships with root diameter are characterized by power or exponential relations, consistent with the MohrCoulomb law. Root mechanical strength reflects their anatomical structure, especially the percentage of phloem and xylem cells, and the degree and speed of periderm lignifications. The cohesion force of rootsoil composite systems is notably higher than that of soil without roots, with increasing amplitudes of cohesion force for A. canescens, C. korshinskii, $Z$. xanthoxylon, $N$. tangutorum and $L$. chinense of $75.9 \%, 75.1 \%, 36.2 \%, 24.6 \%$ and $17.0 \%$ respectively. When subjected to shear forces, the soil without root samples show much greater lateral deformation than
\end{abstract}

Received: 5 November 2012

Accepted: 2 July 2013 the root-soil composite systems, reflecting the restraining effects of roots. Findings from this paper indicate that efforts to reduce shallow landslides in this region by enhancing root reinforcement will be achieved most effectively using $A$. canescens and $C$. korshinskii.

Keywords: Arid environments; Shallow landslide; Vegetative hillslope protection; Root-soil composite systems; Tensile strength; Root reinforcement

\section{Introduction}

Erosion is a natural phenomenon that frequently impacts on human society. Human activities may accelerate or suppress natural rates of erosion, changing the pattern and rate of activity, potentially bringing about serious local and off-site consequences. As vegetation cover exerts a critical influence upon hillslope stability, these issues are especially pronounced in arid or semi-arid landscapes where vegetation cover is sparse. Hence, use of vegetation as a control upon erosion is an important consideration (Burylo et al. 2011).

Soil erosion is one of many natural hazards in Qinghai Province. Erosion extends over $35.43 \times 10^{4}$ $\mathrm{km}^{2}$ (i.e. $49.21 \%$ of the province), and is expanding at a rate of $0.21 \times 10^{4} \mathrm{~km}^{2}$ annually (Liu 2003; Wang 
et al. 2003). Shallow landslides and debris flows are common, especially following intense storms or extended periods of heavy rainfall (Ren 2004; Zhang et al. 2007). As the slip plane of shallow landslides is relatively near the slope surface (generally no more than $2 \mathrm{~m}$ deep; Zhou et al. 2003; Ji et al. 2012), root strength and density are key considerations in determination of the most appropriate vegetation cover as a part of hillslope management strategies (Thornes 1990; Morgan 1996; Gray and Sotir 1996; Mitsch and Jorgensen 2003; Odum and Odum 2003).

To date, few investigations have assessed the effects of young shrubs for improving hillslope stability (examples include Operstein and Frydman 2000; Mattia et al. 2005; De Baets et al. 2008, 2009). Plants can help prevent soil slippage and improve hillslope stability through mechanical reinforcement of soil by roots (Waldron 1977; Ziemer 1981; Nilaweera and Nutalaya 1999; Stokes et al. 2009). Plant roots provide additional cohesion to soil (Thomas and Pollen-Bankhead 2010; Fan et al. 2012; Mao et al. 2013). Soil strength is influenced by the extent and length of roots within the root-soil composite (e.g. Operstein and Frydman 2000; Nilaweera and Nutalaya 1999; Yang and Shi 2002; Yang et al. 1996; Mickovski and van Beek 2009; Loades et al. 2010) as well as the effect of root area ratio (RAR) (PollenBankhead et al. 2009, 2010; Mao et al. 2012). Mechanical effects of root systems affect the pullout resistance and pull-out strength of root systems, tensile resistance and tensile strength of single roots, and shear resistance and shear strength of single roots (e.g. Hathaway and Penny 1975; Burroughs and Thomas 1977; Schiechtl 1980; Nilaweera and Nutalaya 1999; Greenwood et al. 2004; Genet et al. 2005; Norris 2005). When subject to shear stress, root tensile strength is manifest through the tensile resistance of roots (Wu et al. 1979; Ekanayake and Phillips 1999; Operstein and Frydman 2000). Single root tensile strength decreases via a power relationship as root diameter increases (e.g. Nilaweera and Nutalaya 1999). This reflects differences in root structure, as cellulose content increases as root diameter decreases (i.e. smaller roots have more cellulose per dry mass than larger roots (Turmanina 1965; Hathaway and Penny 1975; Commandeur and Pyles 1991; Genet et al. 2005)). Other important considerations include root system morphology, such as root biomass, root number, root diameter and root length (Wu et al. 1979) and root system architecture (Stokes et al. 1996; Dupuy et al. 2007; Mickovski et al. 2007; Reubens et al. 2007). The most efficient branching pattern is generated when many roots are spread deep into the soil (Stokes et al. 1996; Fan et al. 2010). The optimum branching angle is a vertical angle of $90^{\circ}$ between a lateral root and the main axis, while the mechanically optimal radial angle between a lateral branch and its daughter is between $0-20^{\circ}$ (Stokes et al. 1996; Reubens et al. 2007).

This paper presents the findings of an exploratory analysis into the use of native shrubs that are adapted to the cold climatic conditions of the Qinghai-Tibetan Plateau as a strategy to reduce shallow landslide activity on loess hillslopes. Emphasis is placed upon ranking the effectiveness of five native shrubs based upon root strength. Objectives of this study are as follows:

1. Determine the shear strength of root-soil composite systems for the five selected shrubs and for soil without roots using direct shear and triaxial tests.

2. Establish the relationship between single root tensile resistance (strength), single root shear resistance (strength) and root diameter for the selected shrubs.

3. Assess how the anatomical structure of roots affects their mechanical strength properties, such as tensile resistance (strength).

\section{Methods}

\subsection{Testing areas}

Xining Basin lies within the MesozoicCainozoic fault subsidence basin of the Qilian Mountain fold system. Basement rocks of the basin are composed of Triassic sandstone, siltstone and shale (Zhao et al. 2008). The Tertiary middle stratum is composed of mudstone, gypsum and siltstone. The Quaternary upper stratum is composed of sand, gravel and loess. The latter materials engender complex engineering geology challenges. High porosity and countless vertical joints promote shallow landslide activity. The dense population and frequent engineering 
activities in the area accentuate these problems.

Xining Basin lies within an intermontane valley at the margins of the uplifting Qinghai-Tibet Plateau and the loess plateau. Vegetation cover is relatively limited in this area. In the local watershed, erosion extends over $267.5 \mathrm{~km}^{2}$ of the local catchment area of $350 \mathrm{~km}^{2}$ (i.e. $86.8 \%$; Li et al. 2006). The average soil erosion rate in this area is 4,800 t km-2 $\mathrm{a}^{-1}$ (Yang et al. 2009; Zhang et al. 2007). According to Li et al. (2006), erosion rates are lowest on the gentle hillslopes of valley floors where vegetation cover is higher than 70\% (around 1,000-2,000 $\mathrm{t} \mathrm{km}^{-2} \mathrm{a}^{-1}$ ). Gentle hillslopes typically have average erosion rates of 2,000-5,000 $\mathrm{km}^{-2} \mathrm{a}^{-}$ 1, whereas middle and upper hillslopes have erosion rates of $5,000-8,000 \mathrm{t} \mathrm{km}^{-2} \mathrm{a}^{-1}$, extending to $8,000-12,000 \mathrm{t} \mathrm{km}^{-2} \mathrm{a}^{-1}$ in some areas.

The testing areas for this analysis are located along the Huangshuihe Valley, the most populous area of Qinghai Province $\left(36^{\circ} 35^{\prime} \mathrm{N}, 101^{\circ} 50^{\prime} \mathrm{E}\right.$; mean altitude $2,250 \mathrm{~m}$; Figure 1). The steep hillslopes in this mountainous area have a thick loess cover. The continental semi-arid climate is characterized by long winters and short summers. Mean annual temperature is $4 \cdot 9^{\circ}$. Mean annual rainfall is $367.5 \mathrm{~mm}$, with a mean annual evaporating capacity of $1,729.2 \mathrm{~mm}$. Around $70 \%$ of the annual rainfall occurs between June and September (Ren 2004). Vegetation cover is restricted to the lower hillslopes. Soil erosion, shallow landslides and floods are pronounced during heavy rainstorms in summer (Zhao 1994; Wen 1999). Three testing areas were established around Xining Basin ( $\mathrm{Hu}$ et al. 2011): Honggou ditch is a high hillslope testing area in Chengdong district, while lower hillslope testing areas are located in Gujialinggou ditch in Chengbei district and at Qinghai University in Chengbei district (see Figure 1). The primary experiments were conducted in Honggou ditch testing area. Typical soil erosion and shallow landslide problems in the study areas are exemplified in Figure 2.

\subsection{Shrub selection}

Mechanical properties that assist in the protection of hillslopes in the Xining region were analyzed for five local shrubs: C. korshinskii Kom., N. tangutorum Bobr., Z. xanthoxylon (Bunge) Maxim., A. canescens (Pursh) Nutt. and $L$. chinense Mill. These shrubs have dense root systems and are adapted to the local climate as they are cold tolerant and drought hardy species (Wu et al. 1998).

\subsection{Field and laboratory procedures}

\subsubsection{Field procedures}

Seeds were sown in the testing areas in April 2004. Line seeding at the Honggou ditch high hillslope testing area was applied over an area of $20 \mathrm{~m} \times 15 \mathrm{~m}$ using a line width of $24 \mathrm{~cm}$ and spacing of $10 \mathrm{~cm}$. The dibble seeding method was used to plant shrubs with a seeding depth of 1-2 $\mathrm{cm}$.

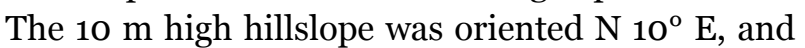
had a slope angle of $40^{\circ}$. Physical and chemical properties of soils in the testing areas are summarized in Table 1.

After two years growth, the entire aboveground part of shrubs, including stems and leaves was collected. Soil without roots and rootsoil composite system samples were taken from the plant's growth position. Both soil without root samples and root-soil composite samples were taken at a depth of $100-150 \mathrm{~cm}$ under the slope surface. The rooted soil $(30 \mathrm{~cm} \times 30 \mathrm{~cm} \times 40 \mathrm{~cm})$ was excavated out carefully, then plastic preservative bags were used to envelop them immediately, and they were put into testing cases and taken back to the laboratory. Indoor direct shear and triaxial tests were performed as soon as possible. Five blocks of soil without root samples and rooted soil samples were taken individually.

\subsubsection{Measurement of root architecture and anatomy}

The root distribution and architecture characteristics of shrubs grown at Honggou ditch were assessed after two years growth. All five shrubs have a vertical root system. To assess root architecture, one or two plants of each kind of shrub were randomly selected in the field. The dry excavation method was conducted, gradually stripping away the soil which surrounded the roots from the slope surface. Measurements were made of growth data such as taproot and lateral root length (using a tape), root width/diameter (using slide calipers) and root orientation (using a graphometer). 


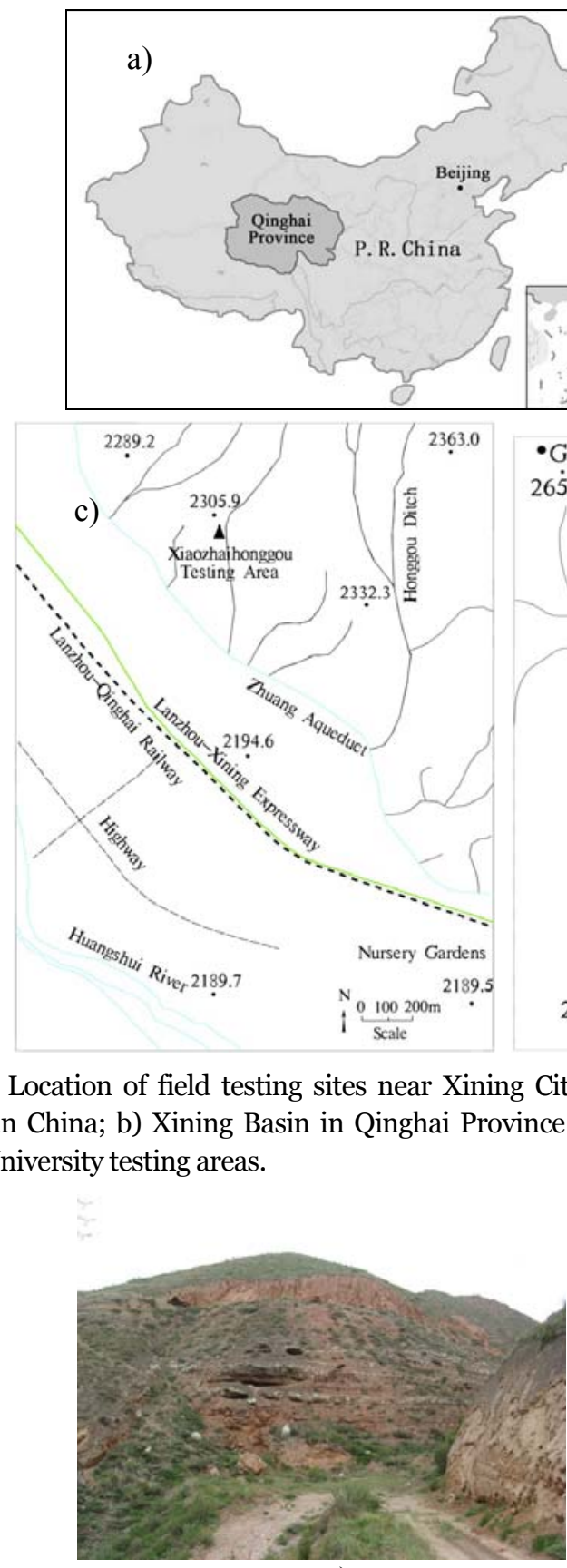

a)

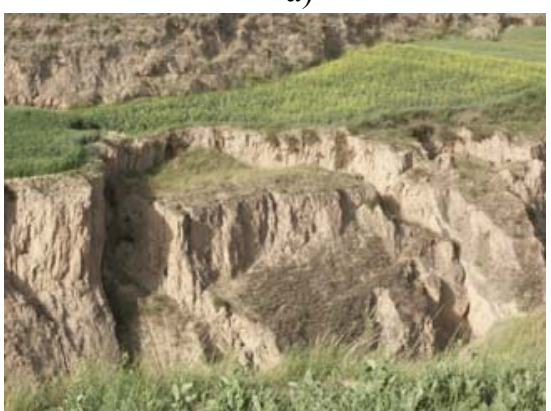

c)
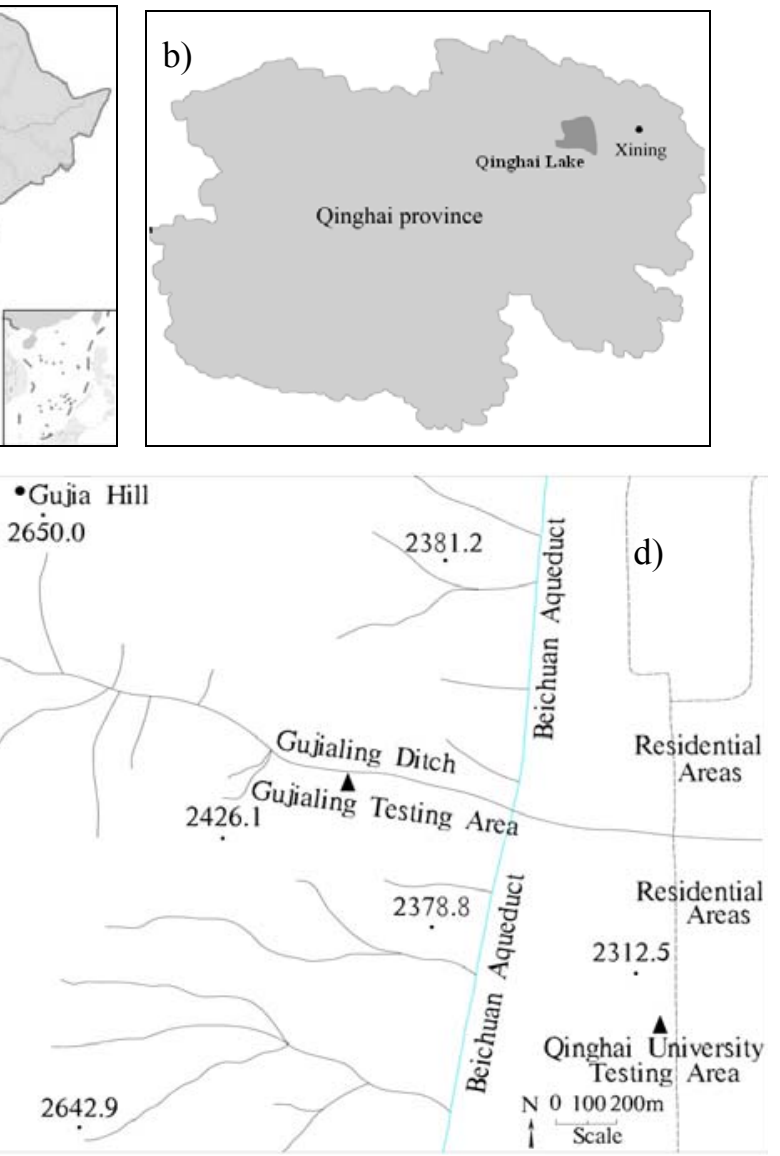

Figure 1 Location of field testing sites near Xining City on the northeast Qinghai-Tibet Plateau in China. a) Qinghai Province in China; b) Xining Basin in Qinghai Province in China; c) Honggou ditch testing area; d) Gujialing ditch and Qinghai University testing areas.

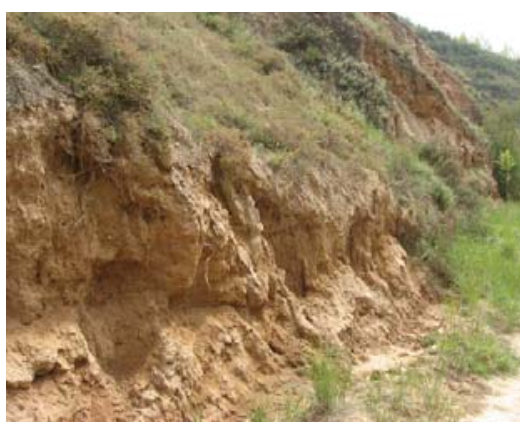

b)

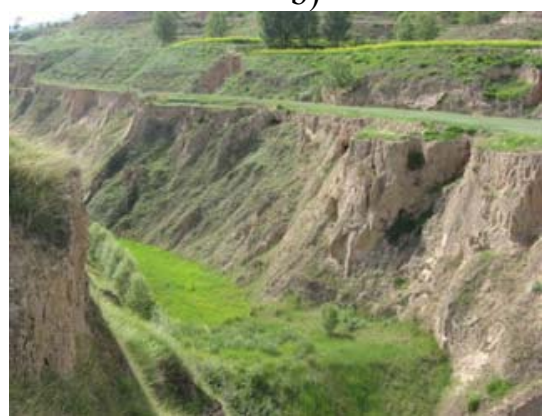

d)

Figure 2 Typical soil erosion and shallow landslides phenomena in the loess-covered Xining region, China. a) Patchy erosion in an area with poor vegetation cover, b) Soil erosion on hillslopes, c) Intensive well-developed shallow landslides, d) Sedimentation in the gully bottom. 
Table 1 Physical and chemical properties of soils at the Honggou ditch testing area, Xining, China

\begin{tabular}{|c|c|c|c|c|c|c|c|c|c|}
\hline \multirow{2}{*}{$\begin{array}{l}\text { Soil } \\
\text { density } \\
\left(\mathrm{g} / \mathrm{cm}^{3}\right)\end{array}$} & \multirow{2}{*}{$\begin{array}{l}\text { Porosity } \\
\text { (\%) }\end{array}$} & \multirow{2}{*}{$\begin{array}{l}\text { Moisture } \\
\text { content } \\
\text { (\%) }\end{array}$} & \multirow{2}{*}{$\mathrm{pH}$} & \multicolumn{3}{|c|}{ Grading analysis (\%) } & \multirow{2}{*}{$\begin{array}{l}\text { Soil } \\
\text { texture }\end{array}$} & \multirow{2}{*}{$\begin{array}{l}\text { Plastic } \\
\text { limit } \\
(\%)\end{array}$} & \multirow{2}{*}{$\begin{array}{l}\text { Liquid } \\
\text { limit } \\
(\%)\end{array}$} \\
\hline & & & & $d<0.05$ & $d<0.01$ & $d<0.002$ & & & \\
\hline 1.58 & 54.82 & 12.80 & 8.13 & 64.96 & 21.88 & 5.74 & Silt & 18.12 & 23.64 \\
\hline
\end{tabular}

Note: Corresponding indexes such as soil moisture content, soil density, etc. were measured separately in July, August and September 2004 during in situ root pull-out tests (the mean value from the three months is shown).

The anatomical structure of roots was tested by cutting 5-10 $\mathrm{mm}$ taproot segments (diameter 1-3 $\mathrm{mm}$, depth 100-150 cm). Five samples were consolidated within a formalin-acetic acid-alcohol (FAA is a fixing agent used to make microtome sections of plants; in this instance it was compounded by alcohol (70\%) $90 \mathrm{~mL}$, acetic acid 4 $\mathrm{mL}$ and formalin $6 \mathrm{~mL}$, and treated by hydrofluoric acid demineralization and alcohol series desiccation (see Zhu et al. 2009)). Permanent slices were embedded within paraffin, stuck by neutral gum, and stained using safranine-fast green (safranine: 1\% water solution, fast green: $0.5 \%$ alcohol; Li 1978). Twenty microtome sections of roots were cut using a rotary microtome. Root cross-sections were characterized under a microscope (OLYMPUS SBX51) using the ImageProplus pattern analysis system. This included analysis of the catheter (the conducting tissue which is made of many cylinder shaped dead cells (vessel elements) in the xylem of shrubs; its function is to transport moisture content and inorganic salt out of shrub roots), percentage of phloem and root diameter thickness.

\subsubsection{Soil mechanical tests}

Direct shear test and triaxial tests were made individually for both rooted soil for the five shrub types and for the soil without roots. Direct shear and triaxial tests were completed for four samples. In order to ensure that the roots used for tensile and shear tests had the same root diameter, given length roots were divided equally into two parts.

Sampling and analysis procedures used to conduct direct shear tests were as follows. First, the moisture content of soil was measured by oven drying (12.8\% in this instance). Then, soil with a moisture content of $12.8 \%$ was mixed with roots of the five shrubs. Efforts were made to replicate characteristics of shrub root distribution in hillslope soils (root diameter is $0.2-1.2 \mathrm{~mm}$, root length is $40 \mathrm{~mm}$, root weight is $1.2 \mathrm{~g}$ ). The sample was placed into a compaction mould (inner diameter $6.18 \mathrm{~cm}$, height $12.5 \mathrm{~cm}$ ). The soil was compacted to a density of $1.58 \mathrm{~g} / \mathrm{cm}^{3}$ (equivalent to soil density on hillslopes of the testing area). Using a cutting ring, samples were made of the compacted soil column (samples have inner diameter of $6.18 \mathrm{~cm}$ and height of $2.0 \mathrm{~cm}$ ). At the beginning of the test, a sample in a cutting ring was fitted into a square metal box (height $2 \mathrm{~cm}$, inner diameter $6.18 \mathrm{~cm}$ ) which was split into two halves horizontally. A pressure pad was put on top and the box was placed on a roller bearing. A vertical load was then applied to the specimen by means of a static weight hanger, so that the soil specimen was sheared by applying a continuous horizontal shearing force at a constant rate on the lower half of the sample until shear failure occurred. Straincontrolled direct shear tests were performed using ZJ equipment (Nanjing Soil Instrument Factory Co., Ltd). Direct shear experiments were conducted for four samples under four vertical pressures (50, loo, 200 and $300 \mathrm{kPa}$ ). They were completed twice for the root-soil composite system and the soil without roots. The applied rate of shear was 2.4 $\mathrm{mm} / \mathrm{min}$.

Initial steps in sampling and analysis procedures used to conduct triaxial tests on soil without roots and soils with shrub roots followed steps outlined for the direct shear tests. Once more, soil with a moisture content of $12.8 \%$ was mixed with roots of the five shrubs. Efforts were made to replicate characteristics of shrub root distribution in hillslope soils (four roots with diameter $1.66 \mathrm{~mm}$ and length $120 \mathrm{~mm}$ were mixed vertically and evenly for each shrub). Each sample was placed into a compaction mould (inner diameter $6.18 \mathrm{~cm}$, height $12.5 \mathrm{~cm}$ ). More soil was progressively added and fifteen lateral roots (length $50 \mathrm{~mm}$, diameter $0.48 \mathrm{~mm}$ ) were horizontally put in at 30,60 and 90 $\mathrm{mm}$ depth beneath the surface of compact moulds. Samples were compacted continuously until the density reached $1.58 \mathrm{~g} / \mathrm{cm}^{3}$ (equivalent to soil density on hillslopes of the testing area; Figure 3 ). 
At the beginning of the test, the finished sample was fitted into a membrane tube. This was then sealed by a rubber membrane, put into a pressure cell and covered with a load cap. Next, the cell was filled with water to subject the sample to an isotropic confining pressure from three directions. With the cell pressure being constant, the vertical load was then applied externally and increased steadily by a transmission pressure piston connecting rod. This generated shear stress in the inner part of the sample. Shear stress increased with vertical load until one or two failure planes occurred within the sample. Triaxial tests were performed using TCK-1 measuring control apparatus (Nanjing Soil Instrument Factory Co., Ltd). Unconsolidated-undrained triaxial tests were applied to four replicate samples under four confining pressures $(10,20,30$ and $40 \mathrm{kPa})$. The applied rate of shear was $0.8 \mathrm{~mm} / \mathrm{min}$.

\subsubsection{Root mechanical tests}

The roots used for single tensile and shear tests were excavated from hillslope soil, sealed with preservative film, and taken backed to the laboratory where single root tensile and shear tests were conducted as soon as possible. Fresh roots were used for both single root tensile and shear tests. The maximal tensile force (or shear force) and displacement of single roots were recorded. Single roots of 2-10 $\mathrm{cm}$ length were clamped onto a test-working platform. Tensile force (single root maximal stretching resistance when stretched) was then applied (and measured) until the root was broken (see Zhu et al. 2008). Single root tensile strength, $P$, was calculated as:

$$
P=\frac{4 F}{\pi D^{2}}
$$

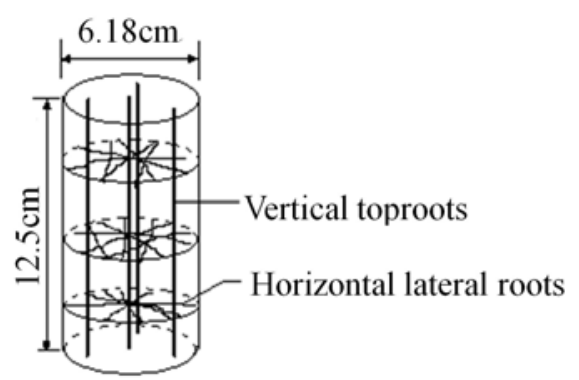

Figure 3 Root distribution within soil-root composite system specimen manufactured for triaxial compression test where $P$ is single root tensile strength ( $\mathrm{MPa}), F$ is maximal tensile resistance $(\mathrm{N})$, and $D$ is single root diameter (mm).

To derive single root shear strength, a single root of 2-5 cm length was clamped to the working platform, and shear force (maximal resistance of single root to shear when being sheared) applied using upper and lower clamping fixtures until the root was broken (Zhu et al. 2008). The equation to calculate single root shear strength is:

$$
\tau_{\mathrm{b}}=\frac{P_{\mathrm{b}}}{2 A_{0}}=\frac{2 P_{\mathrm{b}}}{\pi D^{2}}
$$

where $\tau_{\mathrm{b}}$ is single root shear strength (MPa), $P_{\mathrm{b}}$ is maximal shear resistance $(\mathrm{N}), A_{0}$ is single root original sectional area $\left(\mathrm{mm}^{2}\right)$ and $D$ is single root diameter (mm).

Selected root lengths closely simulate field conditions. Root diameter was accurately measured using slide calipers. Force was applied by turning a hand wheel with a mean rotational speed of $6.4 \mathrm{~mm} / \mathrm{min}$ using dynamic strain apparatus (DH5937, Suzhou Donghua Examination Apparatus Co., Ltd).

\section{Results}

\subsection{Physical attributes of plant roots}

Physical attributes of sampled plant roots were as follows. C. korshinskii had a taproot length of $2.58 \pm 0.42 \mathrm{~m}$, a root diameter of $5.36 \pm 1.78 \mathrm{~mm}$, and a root width of $1.62 \pm 0.54 \mathrm{~m}$. Tap and lateral roots were equally developed, and were especially dense at a depth of $0.65 \pm 0.31 \mathrm{~m}$. A. canescens had a taproot length of $4.48 \pm 1.32 \mathrm{~m}$, five times the height of the plant. Its root diameter was $7.16 \pm$ $2.07 \mathrm{~mm}$, while the root width was $2.25 \pm 0.76 \mathrm{~m}$. Lateral roots and capillary roots of this deeprooted shrub were intensively developed at a depth of $0.85 \pm 0.56 \mathrm{~m}$. The root distribution was especially well-developed in the upper $0-50 \mathrm{~cm}$ of the soil, gradually decreasing from $50-100 \mathrm{~cm}$, but with a notable decrease beyond $100 \mathrm{~cm}$ (see Figure 4). Z. xanthoxylon had a taproot length of $1.28 \pm$ $0.24 \mathrm{~m}$, root diameter of $8.16 \pm 2.04 \mathrm{~mm}$, and a root width of $2.87 \pm 1.35 \mathrm{~m}$. Lateral roots of this shallow rooted shrub were many times longer than the taproot. Lateral roots appeared at $0.1 \mathrm{~m}$ 


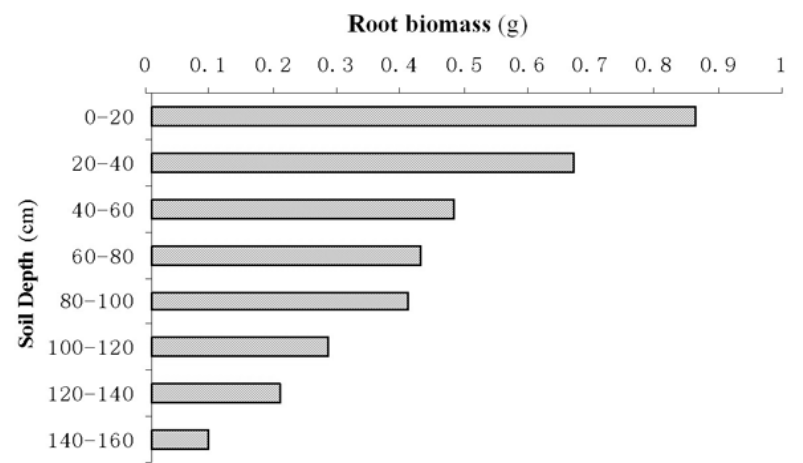

Figure 4 Relationship between average root biomass and underground depth of two-year-old $A$. canescens

underground. They had a near-perpendicular form, growing approximately parallel to the ground surface. $N$. tangutorum had a taproot length of 1.72 $\pm 0.23 \mathrm{~m}$, a root diameter of $6.63 \pm 2.45 \mathrm{~mm}$, and a root width of $1.28 \pm 0.24 \mathrm{~m}$. Lateral roots were intensively distributed between $0.50 \pm 0.22 \mathrm{~m}$. Finally, $L$. chinense had a taproot length of $2.48 \pm$ $0.50 \mathrm{~m}$, a root diameter of $5.16 \pm 2.08 \mathrm{~mm}$, and a root width of $0.88 \pm 0.36 \mathrm{~m}$. Lateral roots were intensively distributed at a depth of $0.57 \pm 0.24 \mathrm{~m}$.

The secondary phloem of $A$. canescens and $C$. korshinskii accounted for $35 \%$, and $45 \%$ of the total root cross sections individually (Figure 5a), and their secondary xylem accounted for 50\%, and 35\% of the total cross sections individually (Figure $5 \mathrm{~b}$ ). The secondary phloem of $Z$. xanthoxylon, $N$. tangutorum and $L$. chinense accounted for 35,30 and $35 \%$ of the total root cross sections individually (Figure 5c-f), and their secondary xylem accounted for $25 \%, 30 \%$ and $25 \%$ of the total root cross sections individually (Figure $5 \mathrm{c}-\mathrm{f}$ ). The phellem layer cell wall of $C$. korshinskii root was thin and the suberin was shrunk. A larger number of bast fibers with a fascicular shape existed in the surface of vascular cambium, the biggest portion among the five shrubs. Clusters of wood fiber existed around xylem. The wood-parenchymatous cell wall of $A$. canescens roots was thick. The distribution of xylogen was fascicular. The vessel wall was lignified with a mean thickness of $20 \mu \mathrm{m}$ (4-5 times the thickness of the other four species). Roots of $Z$. xanthoxylon had a fleshy phellem layer cell wall and watery sap in the protoplast. They had relatively low bast fiber content in their secondary phloem thin wall cells. The secondary phloem and secondary xylem of $N$. tangutorum and $L$. chinense took up a smaller proportion of the root cross sections. The phellem layer cell wall of their roots was thin and the suberin was shrunk. Wood fiber

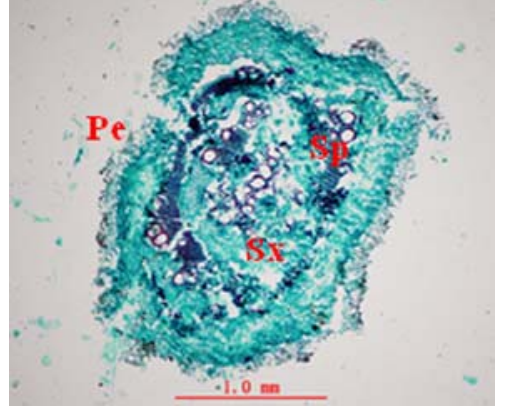

a)

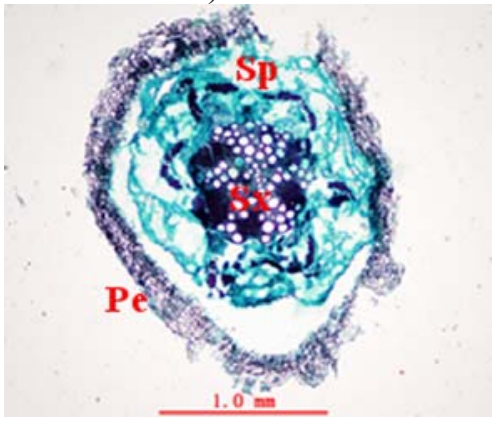

d)

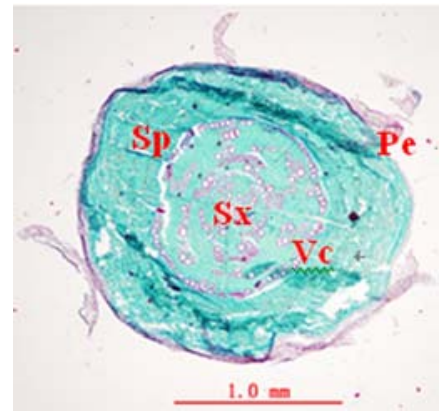

b)

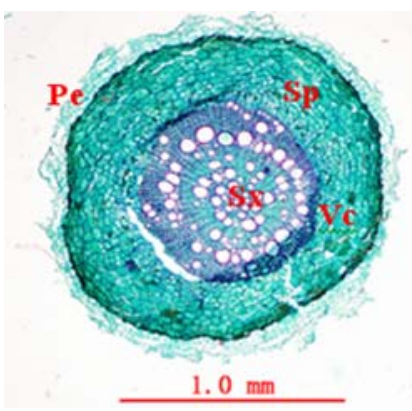

e)

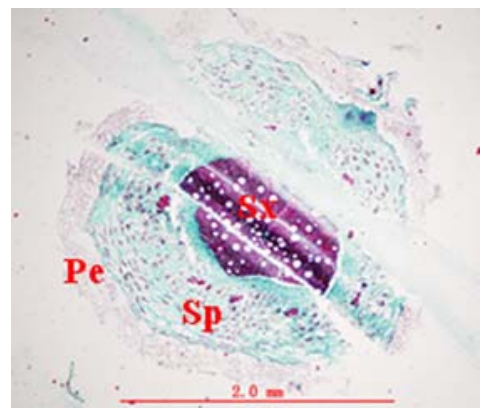

c)

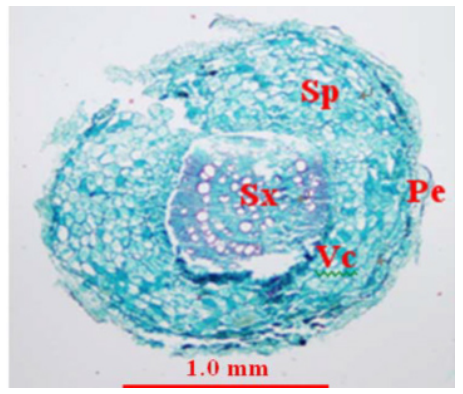

f)

Figure 5 Cross section of shrub roots at 40 times magnification, showing their anatomical structures; a) $A$. canescens, b) C. korshinskii, c) Z. xanthoxylon, d) N. tangutorum e) L. chinense, f) L. chinense, where Sx = secondary xylem, $\mathrm{Sp}=$ secondary phloem, $\mathrm{Pe}=$ periderm and $\mathrm{Vc}=$ vascular cambium 
content was low in L. chinense secondary xylem.

\subsection{Direct shear tests}

Direct shear test results for both root-soil composite systems and soil without roots show clear trend line relationships between shear strength and vertical pressure ( $\tau-\sigma$; Figure 6a-f). When the roots and moisture content of root-soil composite systems are kept constant, the shear strength of the root-soil composite system increases linearly with increasing vertical pressure (correlation greater than 0.99). A direct relationship is also evident between the shear strength of root-soil composite systems and normal pressure on the vertical shear plane. The direct shear strength of the root-soil composite systems agrees with the Mohr-Coulomb law ( $\tau=c$ $+\sigma \tan \varphi)$.

Roots increase soil strength. For example, the root-soil composite system shear strength of $A$.

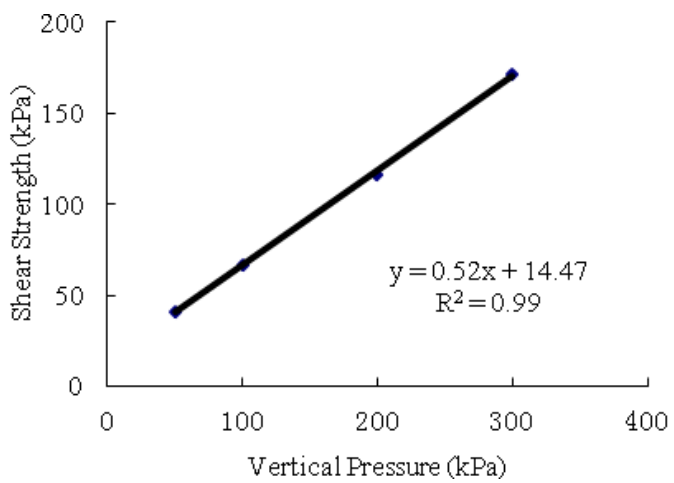

a)

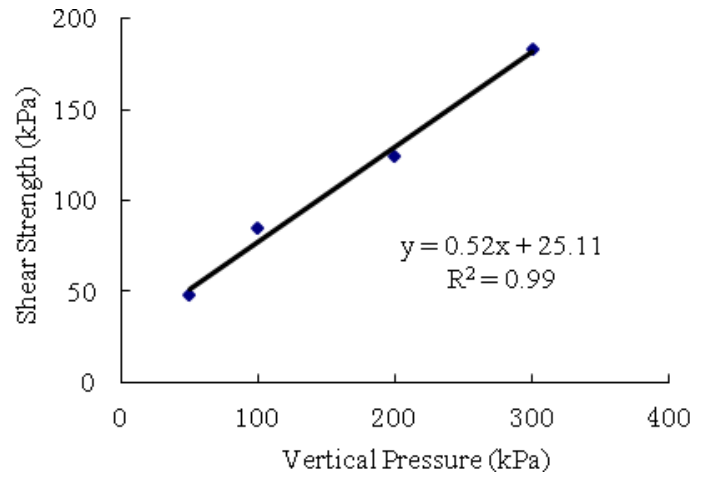

c)

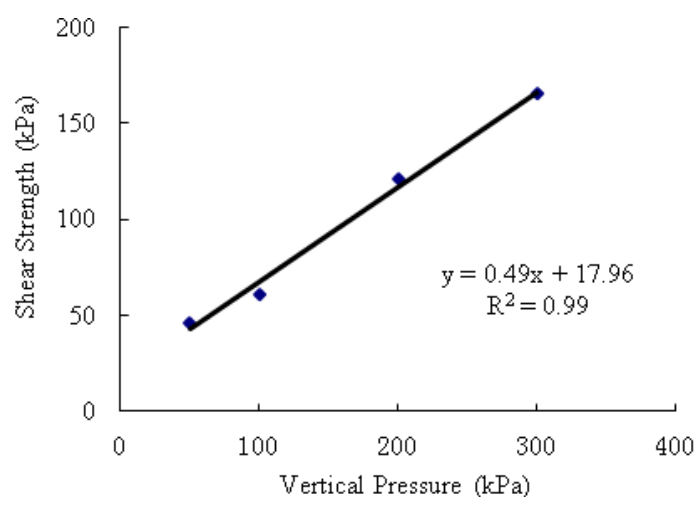

e)

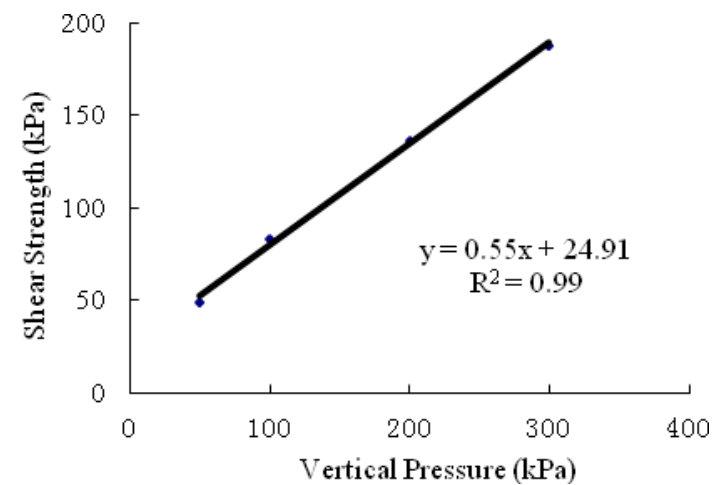

b)

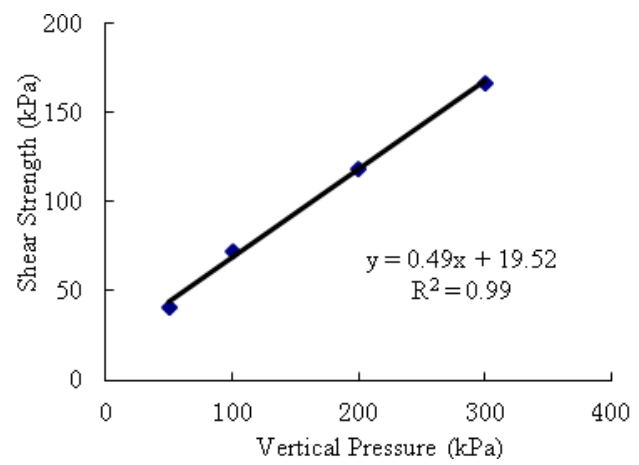

d)

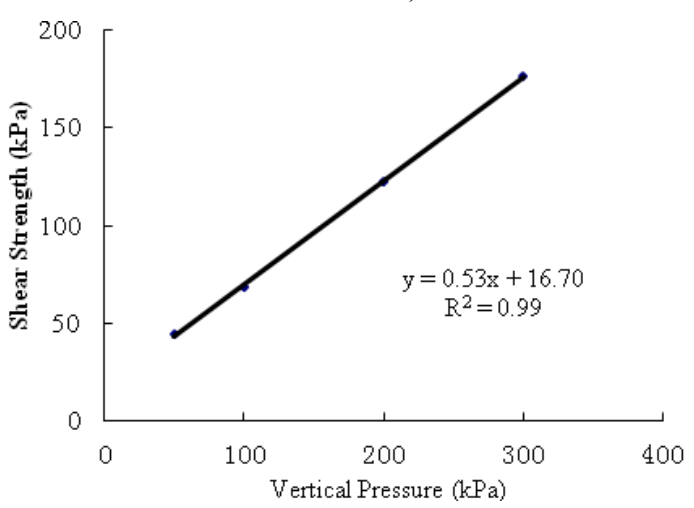

f)

Figure 6 Relationship between shear strength ( $\tau$ ) and vertical pressure ( $\sigma$ ) for soil-root composite system and soil without roots. a) soil without roots; b) A. canescens; c) C. korshinskii; d) Z. xanthoxylon; e) N. tangutorum; f) L. chinense. In these relationships, soil cohesive strength $(c)$ is shown by the y intercept, while soil internal friction angle $(\varphi)$ is represented by the angle between the line and the horizontal ordinate. 
canescens was $82.9 \mathrm{kPa}$ when vertical pressure was $100 \mathrm{kPa}$ (Figure 7). This is approximately $25 \%$ greater than the shear strength of soil without roots. The reinforcing effect provided by roots adds a cohesion force $(\triangle c)$ (see Table 2). The cohesion force of the root-soil composite system for $A$. canescens is notably greater than that of the soil without roots, with an incremental cohesion force value of $10.442 \mathrm{kPa}$ (Figure 7; around $72 \%$ greater than soil without roots). However, the internal friction angle of both the root-soil composite system and soil without roots did not change in a systematic manner. In summary, the following sequence of cohesion forces was found for the five-shrub root-soil composite systems: $A$. canescens $>C$. korshinskii $>$ Z. xanthoxylon $>N$. tangutorum $>L$. chinense $>$ soil without roots.

\subsection{Unconsolidated-undrained triaxial test results}

\subsubsection{Main stress difference and axial strain}

Stress-strain data for shear tests of root-soil composite systems and soil without roots were used to determine the main stress difference and

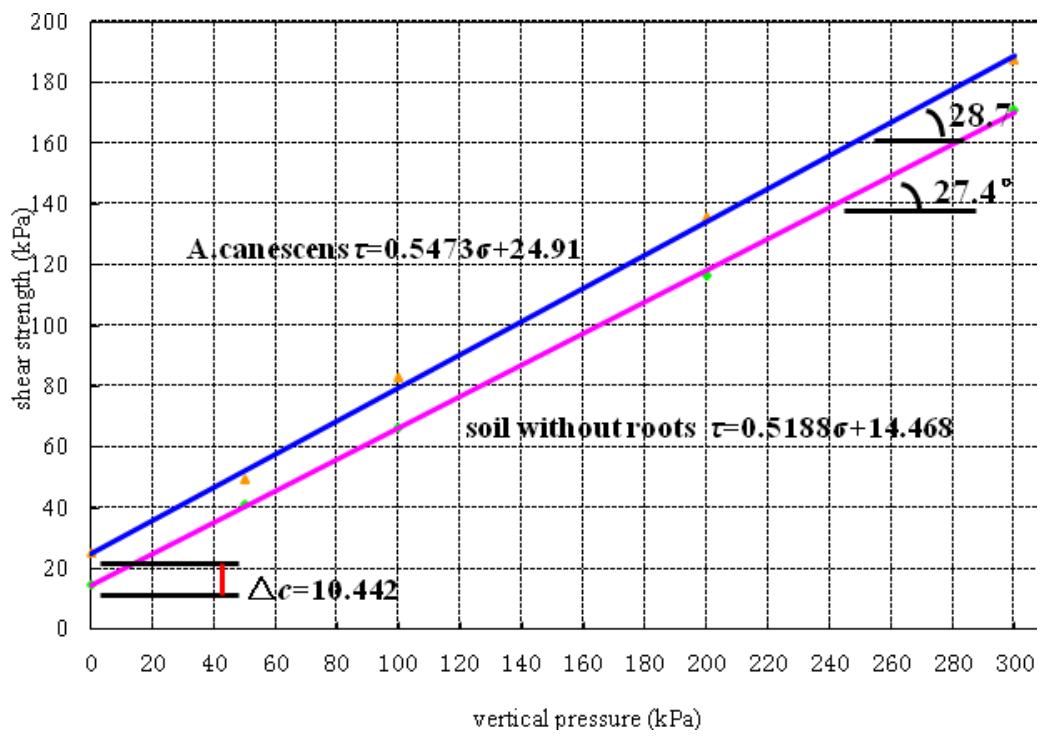

Figure 7 Relationship between shear strength $(\tau)$ and vertical pressure $(\sigma)$ between soil-root composite system of $A$. canescens and soil without roots

Note: Average values of cohesion force (c) and internal friction angle $(\varphi)$ are derived from $\leq 3$ samples.

axial strain (Figure 8). When strain was $<_{2} \%$, the stress-strain relationship curves for root-soil composite systems and soil without roots are relatively similar. However, when axial strain gradually increases, there are obvious differences for stress-strain curves between root-soil composite systems and soil without roots. Eventually, however, the two curves trend towards a constant value. This indicates that the greatest contribution of reinforced soil by roots occurs under higher axial strains. As the confining pressure continuously increases, the initial

Table 2 Average shear strength results for soil without roots and root-soil composite systems of direct shear tests and triaxial tests

\begin{tabular}{|c|c|c|c|c|}
\hline \multirow[b]{2}{*}{ Sample } & \multicolumn{2}{|c|}{ Direct shear test } & \multicolumn{2}{|c|}{ Triaxial tests } \\
\hline & $\begin{array}{c}\text { Cohesion force } c \\
(\mathrm{kPa})\end{array}$ & $\begin{array}{l}\text { Internal friction } \\
\text { angle } \varphi\left(^{\circ}\right)\end{array}$ & $\begin{array}{c}\text { Cohesion force } c \\
(\mathrm{kPa})\end{array}$ & $\begin{array}{l}\text { Internal friction } \\
\text { angle } \varphi\left({ }^{\circ}\right)\end{array}$ \\
\hline Soil without roots & 14.30 & 27.0 & 2.95 & 31.57 \\
\hline $\begin{array}{l}\text { Soil-root composite system of } \\
\text { A. canescens }\end{array}$ & 25.15 & 28.3 & 14.59 & 26.19 \\
\hline $\begin{array}{l}\text { Soil-root composite system of } \\
\text { C. korshinskii }\end{array}$ & 25.04 & 27.8 & 9.96 & 33.26 \\
\hline $\begin{array}{l}\text { Soil-root composite system of } \\
\text { Z. anthoxylon }\end{array}$ & 19.48 & 26.0 & 4.58 & 29.77 \\
\hline $\begin{array}{l}\text { Soil-root composite system of } \\
N \text {. tangutorum }\end{array}$ & 17.82 & 26.3 & 3.94 & 29.12 \\
\hline $\begin{array}{l}\text { Soil-root composite system of } \\
\text { L. chinense }\end{array}$ & 16.73 & 27.7 & 3.82 & 28.67 \\
\hline
\end{tabular}

Note: Average values of cohesion force $(c)$ and internal friction angle $(\varphi)$ are derived from $\leq 3$ samples. 


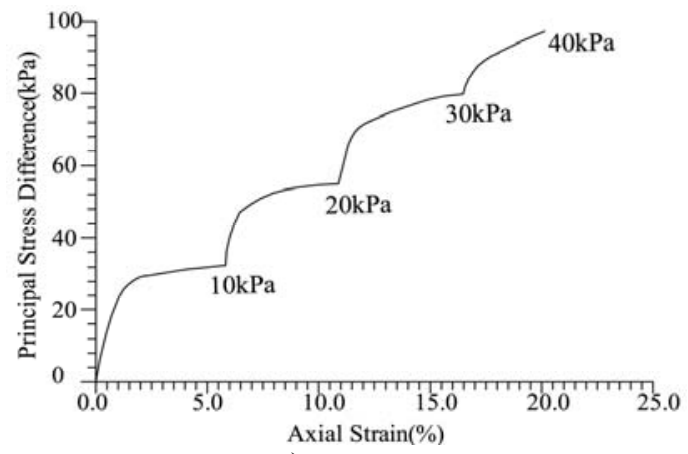

a)

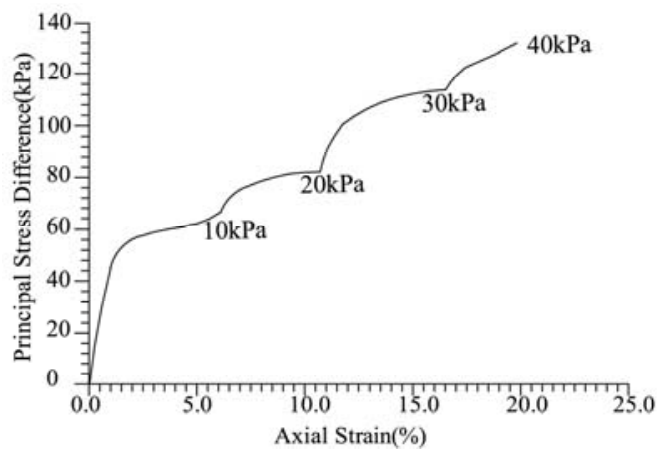

c)

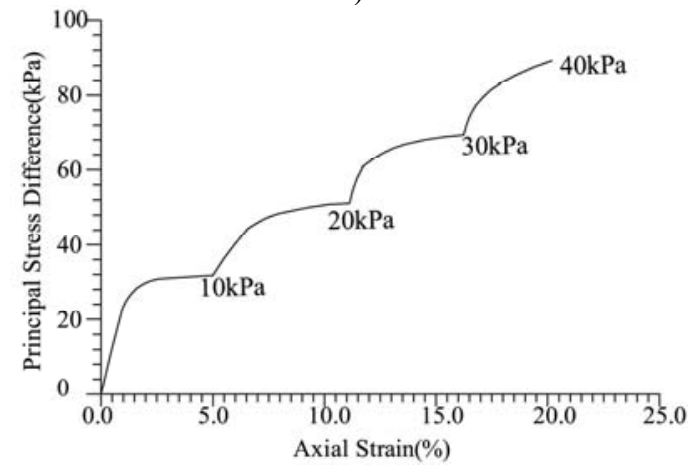

e)

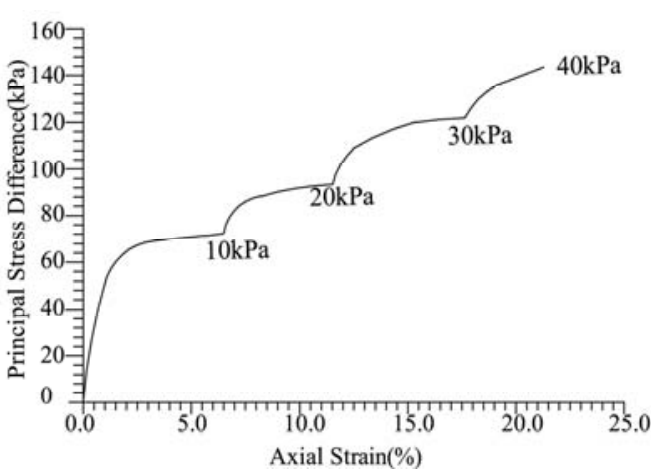

b)

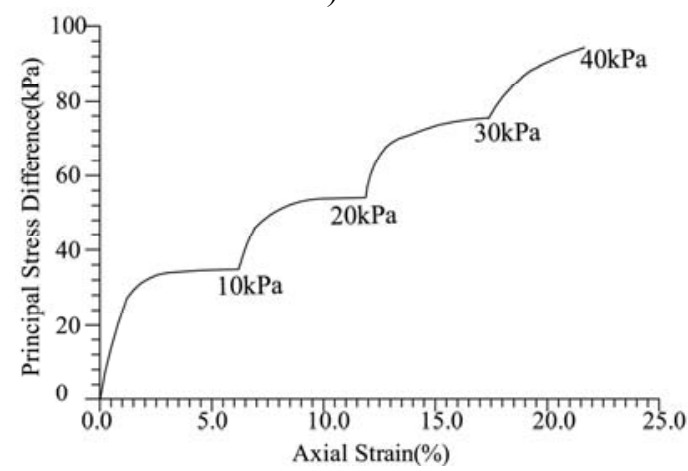

d)

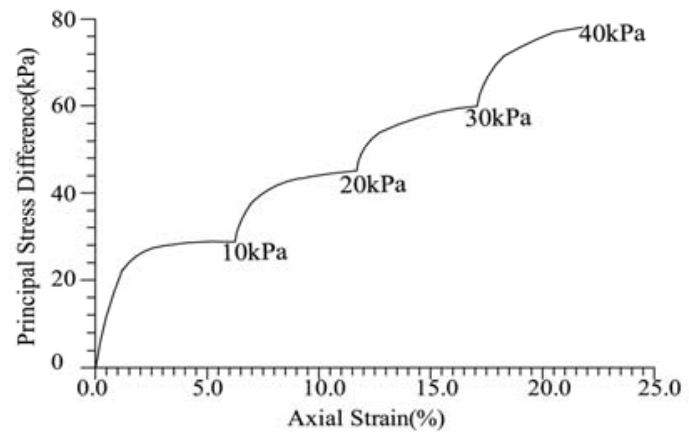

f)

Figure 8 Main stress difference and axial strain curve of soil with roots and soil without roots. a) Soil without roots, b) A. canescens, c) C. korshinskii, d) Z. xanthoxylon, e) N. tangutorum, f) L. chinense

segments of stress-strain relationship curves are linear, demonstrating an elastic character. The shear strength of the root-soil composite systems agrees with the Mohr-Coulomb law (Wu 1976; Waldron 1977; Yang et al. 1996; Liu et al. 2006).

Under identical strain conditions, the main stress difference of root-soil composite systems is notably higher than the soil without roots. Under the same main stress difference value, the strain value of root-soil composite systems is smaller than the soil without roots. This shows that the strength and resistance to deformation ability for root-soil composite systems were reinforced, that is, there is a relatively smaller deformation for rooted soils compared with soil without roots. Based upon the relationship curves between main stress difference and axial strain for the five kinds of shrubs in the testing areas, the strength and resistance to deformation of $A$. canescens and $C$. korshinskii is greater than the other species (Z. xanthoxylon, $N$. tangutorum and $L$. chinense). For example, when the strain value ( $\varepsilon$ ) was $12 \%$, the main stress difference value was $100 \mathrm{kPa}$ for $A$. canescens and C. korshinskii, while the main stress difference value was $65-75 \mathrm{kPa}$ for $Z$. xanthoxylon, $N$. tangutorum and L. chinense. This reflects the potential capacity of root-soil composite systems of A. canescens and $C$. korshinskii to resist soil 
deformation to a greater degree than the other species.

\subsubsection{Shear strength of root-soil composite system}

Mohr's circles of stress and strength envelopes derived for differing confining pressures for soil without roots and root-soil composite systems for the five shrubs are shown in Figure 9. Shear strength indices such as cohesion (c) and internal friction angle $(\varphi)$ are summarized in Table 2. These results show that internal friction angles of both soil without roots and root-soil composite systems were similar. Other than the root-soil

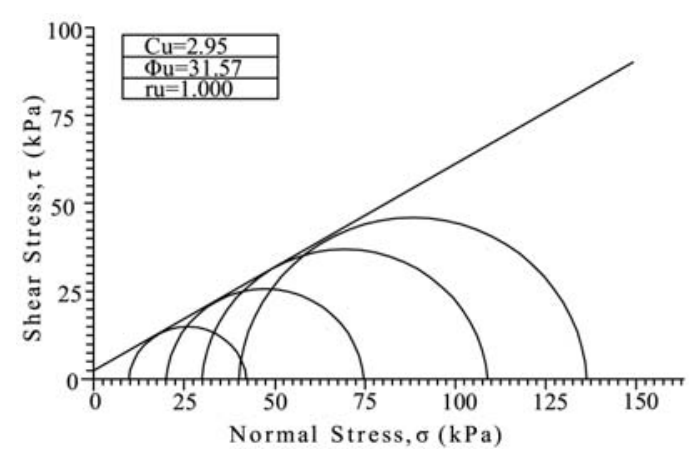

a)

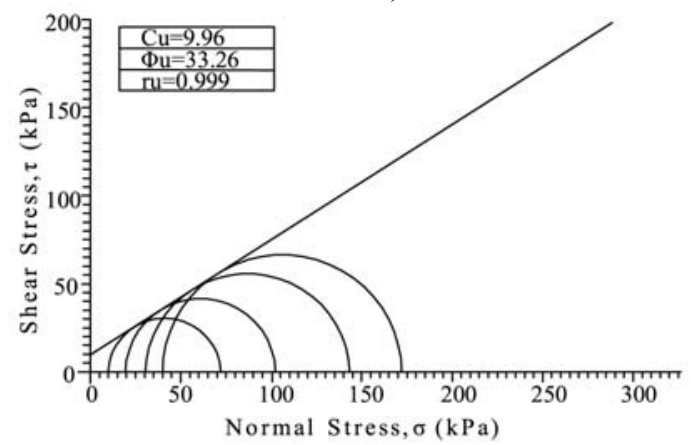

c)

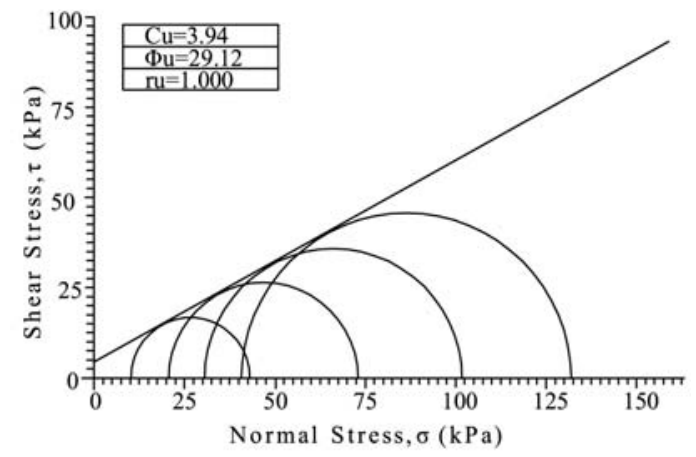

e) composite system for $C$. korshinskii, the internal friction angles of the other four shrub root-soil composite systems were smaller than that of soil without roots. However, the cohesion forces of root-soil composite system are notably higher than the soil without roots, increasing by 29.4-394.6\%. The cohesion force of $14.59 \mathrm{kPa}$ for the shrub rootsoil composite system of $A$. canescens was the biggest among the five kinds of shrub root-soil composite systems. This is approximately five times greater than the cohesion force of soil without roots. In summary, the sequence of cohesion forces for the five-shrub root-soil composite systems mirror the triaxial test results,

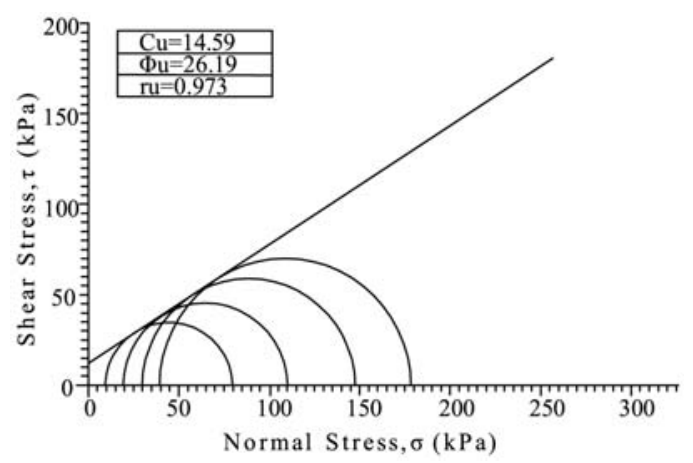

b)

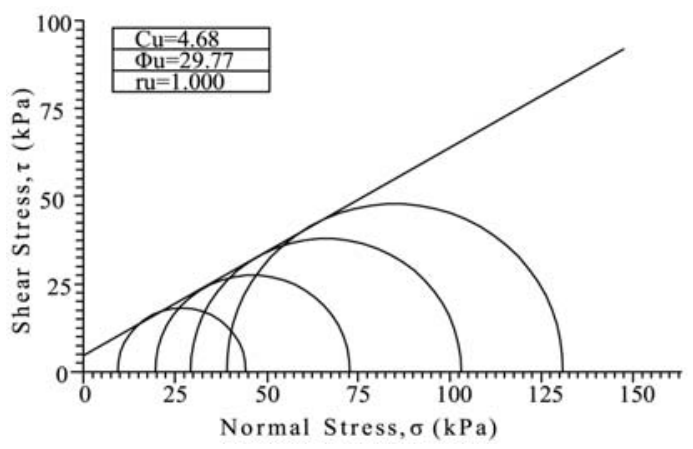

d)

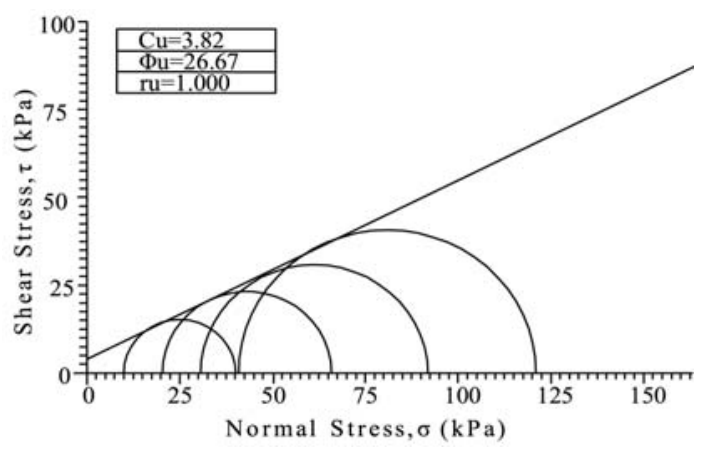

f)

Figure 9 Strength envelope of unconsolidated-undrained triaxial test of root-soil composite system of soil with roots and soil without roots; a) Soil without roots, b) A. canescens, c) C. korshinskii, d) Z. xanthoxylon, e) N. tangutorum, f) L. chinense 
with the following sequence evident: $A$. canescens $>C$. korshinskii $>Z$. xanthoxylon $>N$. tangutorum $>L$. chinense $>$ soil without roots (see Table 2).

\subsubsection{Deformation behaviour of triaxial tests}

Intensification of soil strength by roots is demonstrated through shape change comparison analyses between pre- and post-test samples of shrub root-soil composite systems of $A$. canescens and soil without roots. Soil without root samples had greater lateral deformation in mid-section, creating a "drum" shape (Figure 10a). In contrast, lateral deformation is not obvious in root-soil composite system samples. In these instances, the diameter in the middle section was approximately equivalent with marginal (upper/lower) sections for the post-test samples. These 'deformed' samples did not show an obvious "drum" shape (Figure 10b). The fibrous composite systems of roots and soil are able to adjust to applied stress in a coherent manner, effectively restraining lateral deformation during the shear procedure. Friction between roots and soil increases soil strength via both root tensile strength and soil tensile strength when external loads are applied (Xie et al. 2004; Chen et al. 2007). Also, roots are able to decrease deformation when an identical stress is applied to both roots and soil. Roots have a smaller strain than soil, so they can be considered to be the main reason why root-soil composite system samples have a reduced horizontal strain in their midsection when stress is applied to root-soil composite system samples. Shape deforming degrees for $C$. korshinskii and A. canescens were less than for $Z$. xanthoxylon, $N$. tangutorum and $L$. chinense.

In soil samples without roots, shear plane forms could be observed when axial stress reached its peak value during the triaxial shear test process. These samples were separated into two parts along a shear plane (Figure 11a). Although fracturing also occurred in root-soil composite system samples, intact roots were preserved in these samples
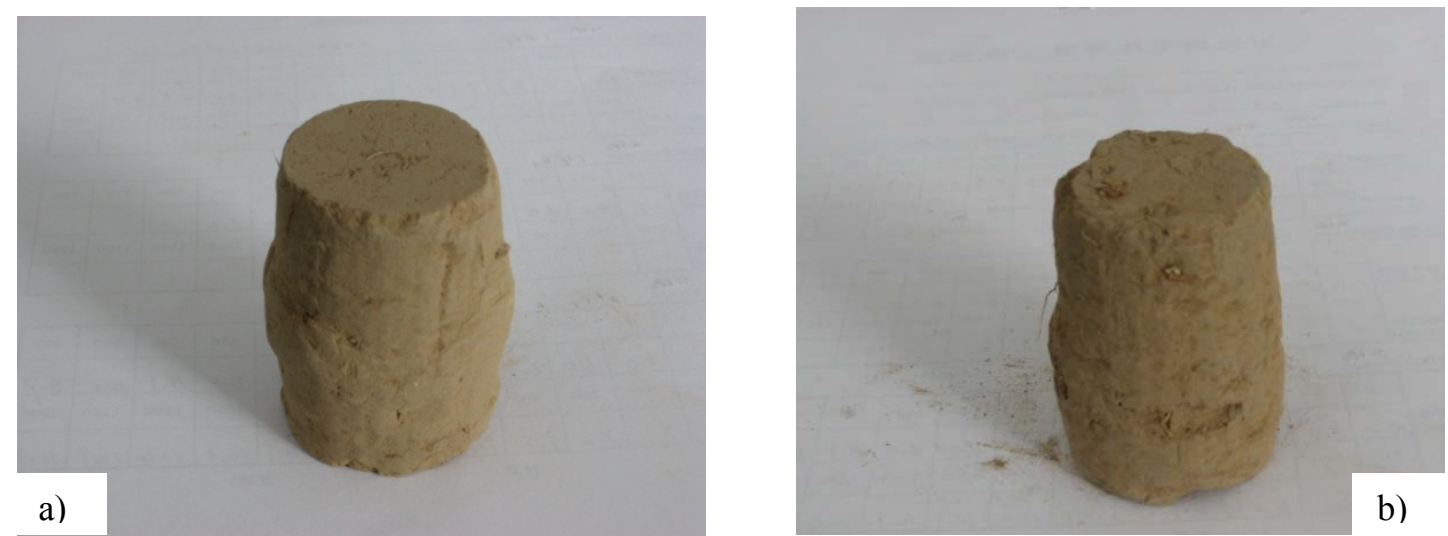

Figure 10 Triaxial tests of deformability for soil without roots and root-soil composite system samples; a) Soil without roots sample shape; b) A. canescens sample shape
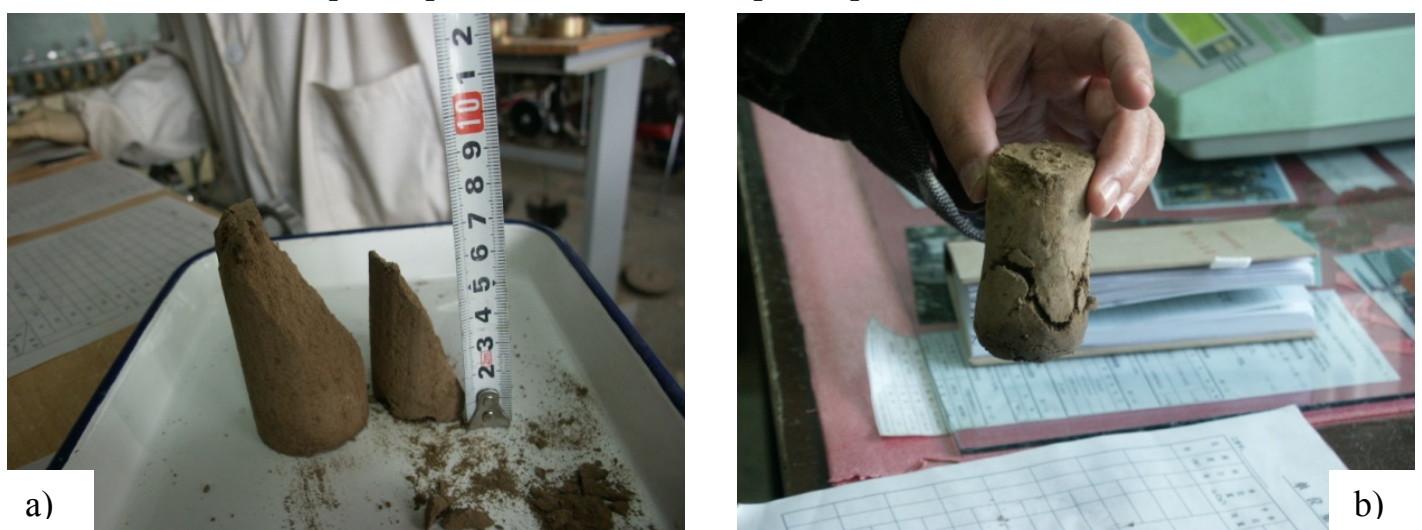

Figure 11 Destructive samples shape characteristics; a) Destructive soil without roots sample shape; b) Destructive $A$. canescens sample shape 
(Figure 11b). For example, the integrity of $A$. canescens samples was retained, with an obvious pulling force of roots along both sides of the fracture plane. Hence, the soil mass is able to endure higher tensile stress. The continuous fracture plane in soil samples without roots attests to the tensile capacity of roots in the root-soil composite system.

\subsection{Root tensile strength and shear strength}

Single root tensile resistance and tensile strength are notably greater for $A$. canescens than for $C$. korshinskii, Z. xanthoxylon, while they are notably smaller for $N$. tangutorum and $L$. chinense (Table 3). There is a positive correlation between single root tensile strength and tensile resistance (i.e. the greater the tensile resistance of a single root, the more obvious its ability to increase soil shear strength). Regression equations for five shrubs between root tensile strength and root diameter are presented in Table 4. There is also a positive correlation between average shear resistance and shear strength (Table 5). Shear strength values for $C$. korshinskii and $A$. canescens are notably bigger than the other shrubs $(Z$. xanthoxylon, $N$. tangutorum and $L$. chinense). Hence, single root shear resistance and strength increase soil shear strength.

Direct shear tests for soil without roots and root-soil composite systems found that the internal friction angle of soil without roots was $27.0^{\circ}$ while the internal friction angles for the five shrub rootsoil composite systems were $26.0-28.3^{\circ}$, with a mean of $27.2^{\circ}$ (Table 2). Internal friction angles for root-soil composite systems of $A$. canescens, $C$. korshinskii and L. chinense were a little larger than that of soil without roots. In contrast, internal friction angles for root-soil composite systems of $Z$. xanthoxylon and $N$. tangutorum were smaller than that of soil without roots.

Triaxial tests for soil without roots and rootsoil composite systems found that the internal friction angle of soil without roots was $31.6^{\circ}$ while the internal friction angles for the five shrub rootsoil composite systems ranged from $26.2-33.3^{\circ}$, with a mean of $29 \cdot 4^{\circ}$. Other than $C$. korshinskii, the internal friction angles of root-soil composite systems were smaller than that of soil without roots.

In summary, results from both direct shear tests and triaxial tests indicate that the internal friction angles for root-soil composite systems were not obviously larger than that of soil without roots.

Table 3 Average single root tensile resistance and tensile strength of five shrubs in the testing area

\begin{tabular}{|l|c|c|c|c|}
\hline Plant types & $\begin{array}{l}\text { Average tensile } \\
\text { resistance }(\mathrm{N})\end{array}$ & $\begin{array}{l}\text { Average tensile } \\
\text { strength }(\mathrm{MPa})\end{array}$ & $\begin{array}{l}\text { Average root } \\
\text { diameter }(\mathrm{mm})\end{array}$ & $\begin{array}{l}\text { Sample number } \\
(\mathrm{n})\end{array}$ \\
\hline A. canescens & $117.84 \pm 23.55$ & $40.28 \pm 8.91$ & $1.93 \pm 0.37$ & 23 \\
\hline C. korshinskii & $57.96 \pm 15.07$ & $26.46 \pm 5.28$ & $1.67 \pm 0.29$ & 22 \\
\hline Z. xanthoxylon & $52.62 \pm 14.90$ & $20.91 \pm 3.87$ & $1.79 \pm 0.32$ & 20 \\
\hline N. tangutorum & $29.32 \pm 5.57$ & $16.12 \pm 2.08$ & $1.56 \pm 0.26$ & 30 \\
\hline L. chinense & $23.95 \pm 5.65$ & $15.92 \pm 1.99$ & $1.53 \pm 0.28$ & 16
\end{tabular}

Table 4 Regression equations between single root tensile strength and diameter of five shrubs in the testing area

\begin{tabular}{|l|l|c|c|c|}
\hline Plant types & Regression equation & $D$ (root diameter in $m m$ ) & $R^{2}$ & Sample number (n) \\
\hline A. canescens & $P=30.195 D^{-0.5299}$ & $0.5 \sim 4.2$ & 0.8170 & 13 \\
C. korshinskii & $P=31.806 D^{-0.4487}$ & $0.4 \sim 2.6$ & 0.8313 & 14 \\
\hline Z. xanthoxylon & $P=25.458 \mathrm{e}^{-0.5053 \mathrm{D}}$ & $0.6 \sim 2.9$ & 0.8030 & 6 \\
\hline N. tangutorum & $P=26.254 \mathrm{e}^{-0.866 \mathrm{D}}$ & $0.6 \sim 2.0$ & 0.7891 & 15 \\
\hline L. chinense & $P=26.467 D^{-1.1125}$ & $1.1 \sim 2.9$ & 0.7430 & 9
\end{tabular}

Table 5 Average single root shear resistance and shear strength of five shrubs in the testing area

\begin{tabular}{|l|l|l|l|c|}
\hline Plant types & $\begin{array}{l}\text { Average shear } \\
\text { resistance }(\mathrm{N})\end{array}$ & $\begin{array}{l}\text { Average shear } \\
\text { strength }(\mathrm{MPa})\end{array}$ & $\begin{array}{l}\text { Average root } \\
\text { diameter }(\mathrm{mm})\end{array}$ & Sample number (n) \\
\hline A. canescens & $160.70 \pm 32.11$ & $28.45 \pm 4.01$ & $2.27 \pm 0.39$ & 23 \\
\hline C. korshinskii & $48.86 \pm 11.78$ & $29.75 \pm 4.60$ & $1.40 \pm 0.23$ & 22 \\
\hline Z. xanthoxylon & $80.20 \pm 15.66$ & $19.52 \pm 3.94$ & $2.00 \pm 0.29$ & 20 \\
\hline N. tangutorum & $68.32 \pm 13.38$ & $16.64 \pm 3.14$ & $2.05 \pm 0.33$ & 30 \\
\hline L. chinense & $61.42 \pm 10.76$ & $13.23 \pm 2.85$ & $1.77 \pm 0.31$ & 16 \\
\hline
\end{tabular}




\subsection{Relationship between anatomical structure of roots, mechanical characteristics of single roots and root-soil composite systems}

The anatomical structure of two year old sample roots of the five shrubs is summarized in Table 6. The periderm of the five shrubs was composed of 3-7 layers of square or polygon shaped cells in an orderly manner, about $100 \mu \mathrm{m}$ in thickness. Secondary xylem areas of both $A$. canescens and $C$. korshinskii made up about $5^{0}$ and $35 \%$ of the root cross section respectively (other roots were less than 35\%). Secondary phloem areas of C. korshinskii made up about $45 \%$ of the root cross section, the biggest among the five shrubs (others were less than 35\%). The vessel area of the five shrubs made up about 8$15 \%$ of secondary xylem areas. Its diameter was about 15 100 $\mu \mathrm{m}$ and wall thickness was about 4$20 \mu \mathrm{m}$.

These preliminary findings indicate that the higher the wood fiber and bast fiber contents of root anatomical structure, the stronger the root's mechanical strength (single tensile resistance and tensile strength). In other words, the greater the percentage of secondary phloem and xylem in root cross section, the higher the root strength.

\section{Discussion}

Root-soil interactions enhance hillslope stability. Results from direct shear test and triaxial

Table 6 Principal characteristics for root anatomical structure of five shrubs in the testing area

\begin{tabular}{|c|c|c|c|c|}
\hline Plant types & Periderm & Secondary phloem & Secondary xylem & Vessel \\
\hline A. canescens & $\begin{array}{l}\text { Periderm is composed } \\
\text { of } 3-4 \text { layers of } \\
\text { polygon cells in an } \\
\text { orderly manner, about } \\
120 \mu \mathrm{m} \text { in thickness. }\end{array}$ & $\begin{array}{l}\text { Area of secondary } \\
\text { phloem makes up about } \\
35 \% \text { of root cross section } \\
\text { area. }\end{array}$ & $\begin{array}{l}\text { Area of Secondary } \\
\text { xylem makes up } \\
\text { about } 50 \% \text { of root } \\
\text { cross section area. }\end{array}$ & $\begin{array}{l}\text { Vessel area makes up } \\
\text { about } 12 \% \text { of } \\
\text { secondary xylem area. } \\
\text { Its diameter is about } \\
20 \sim 80 \mu \mathrm{m} \text { and its } \\
\text { wall thickness is } \\
\text { about } 20 \mu \mathrm{m} \text {. }\end{array}$ \\
\hline C. korshinskii & $\begin{array}{l}\text { Periderm is composed } \\
\text { of } 4-5 \text { layers of } \\
\text { polygon cells in an } \\
\text { orderly manner, about } \\
100 \mu \mathrm{m} \text { in thickness. } \\
\text { Secretory canals in the } \\
\text { periderm are mature. }\end{array}$ & $\begin{array}{l}\text { Area of secondary } \\
\text { phloem makes up about } \\
45 \% \text { of root cross } \\
\text { section. The thin walls of } \\
\text { secondary phloem } \\
\text { contain some granular or } \\
\text { lumpy reserve } \\
\text { substances. }\end{array}$ & $\begin{array}{l}\text { Area of secondary } \\
\text { xylem makes up } \\
\text { about } 35 \% \text { of root } \\
\text { cross section. }\end{array}$ & $\begin{array}{l}\text { Vessel area makes up } \\
\text { about } 8 \% \text { of } \\
\text { secondary xylem area. } \\
\text { Its diameter is about } \\
15 \sim 65 \mu \mathrm{m} \text { and wall } \\
\text { thickness is about } 4 \\
\mu \mathrm{m} \text {. }\end{array}$ \\
\hline Z. xanthoxylon & $\begin{array}{l}\text { Periderm is composed } \\
\text { of } 5-7 \text { layers of square } \\
\text { or polygon cells in an } \\
\text { orderly manner, about } \\
210 \mu \mathrm{m} \text { in thickness. }\end{array}$ & $\begin{array}{l}\text { Area of secondary } \\
\text { phloem makes up about } \\
35 \% \text { of root cross section } \\
\text { area. Parenchyma cells } \\
\text { are developed, } \\
\text { containing many } \\
\text { granular or lumpy } \\
\text { reserve substances. }\end{array}$ & $\begin{array}{l}\text { Area of secondary } \\
\text { xylem makes up } \\
\text { about } 25 \% \text { of root } \\
\text { cross section. }\end{array}$ & $\begin{array}{l}\text { Vessel area makes up } \\
\text { about } 15 \% \text { of } \\
\text { secondary xylem area. } \\
\text { Its diameter is about } \\
25 \sim 60 \mu \mathrm{m} \text { and its } \\
\text { wall thickness is } \\
\text { about } 4 \mu \mathrm{m} \text {. }\end{array}$ \\
\hline N. tangutorum & $\begin{array}{l}\text { Periderm is composed } \\
\text { of 5-7 layers of } \\
\text { rectangle cells in an } \\
\text { orderly manner, about } \\
210 \mu \mathrm{m} \text { in thickness. }\end{array}$ & $\begin{array}{l}\text { Area of secondary } \\
\text { phloem makes up about } \\
30 \% \text { of root cross section } \\
\text { area. }\end{array}$ & $\begin{array}{l}\text { Area of secondary } \\
\text { xylem makes up } \\
\text { about 30\% of root } \\
\text { cross section. }\end{array}$ & $\begin{array}{l}\text { Vessel area makes up } \\
\text { about } 15 \% \text { of } \\
\text { secondary xylem. Its } \\
\text { diameter is about } \\
20 \sim 100 \mu \mathrm{m} \text { and its } \\
\text { wall thickness is } \\
\text { about } 5 \mu \mathrm{m} \text {. }\end{array}$ \\
\hline L. chinense & $\begin{array}{l}\text { Periderm is composed } \\
\text { of } 4-6 \text { layers of square } \\
\text { or polygon cells in an } \\
\text { orderly manner, about } \\
110 \mu \mathrm{m} \text { in thickness. }\end{array}$ & $\begin{array}{l}\text { Area of secondary } \\
\text { phloem makes up about } \\
35 \% \text { of root cross } \\
\text { section. }\end{array}$ & $\begin{array}{l}\text { Area of secondary } \\
\text { xylem makes up } \\
\text { about } 25 \% \text { of root } \\
\text { cross section area. }\end{array}$ & $\begin{array}{l}\text { Vessel area makes up } \\
\text { about } 15 \% \text { of } \\
\text { secondary xylem area. } \\
\text { Its diameter is about } \\
20 \sim 70 \mu \mathrm{m} \text { and its } \\
\text { wall thickness is } \\
\text { about } 4 \mu \mathrm{m} \text {. }\end{array}$ \\
\hline
\end{tabular}

Note: Number of samples (n) is 20 
tests show that the shear strength of soil without roots is lower than the shear strength of root-soil composite systems (Waldron 1977; Waldron and Dakessian 1981; Ziemer 1981; Operstein 2000; Nilaweera and Nutawera 1999; Ekanayake and Phillips 1999; Wu et al. 1979). The greater the tensile strength (or shear strength) of a single root, the stronger its ability to reinforce soil shear strength (Gray and Sotir 1996; Zhu et al. 2008; Hu et al. 2009; Yang et al. 2009). The extent to which shear stress acting on the soil can be transferred into tensile resistance of roots reflects root tensile strength (Operstein et al. 2000; Burylo et al. 2011). At the time of failure, roots within the failure zone may break due to tension, be sheared, or be pulled out (Nilaweera and Nutawera 1999). Of the five shrubs analysed in this study, root tensile strength is far greater for $A$. canescens and $C$. korshinskii than it is for $Z$. xanthoxylon, $N$. tangutorum and $L$. chinense.

Analysis of incremental increases in soil shear strength by shrub roots reflects the distribution and architecture of root patterns and their anatomical structure (Zhu et al. 2009). The main factors affecting the tensile and shear strength of single roots include the percentage of phloem fibers and wood fibers and the degree and rate of periderm lignification. The elongation rate of single roots varied directly with the percentage area of secondary phloem, and inversely with the percentage area of xylem. The reinforcement effects of plant roots reflect their tensile, compression and bending resistances, which in turn are determined by their composition of cellulose, semi-cellulose, lignin, protein and pectin (Xiao 2004). Other researchers (e.g. Waldron and Dakessian 1981; Liu et al. 1996; Zhu et al. 2002; Genet et al. 2005; Li et al. 2005; Guo et al. 2006; Zhao and Zhang 2007) highlighted the correlation between root strength, elongation rate, and Young's modulus of roots with their anatomical structure and chemical constituents. Polyphase, heterogeneity and anisotropic properties of roots reflect their metabolism activities (Guo et al. 2006; Liu et al. 1996). This primarily reflects difference in root architectures, which in turn reflects the higher cellulose content of smaller root diameters (Commandeur and Pyles 1991; Hathaway and Penny 1975; Genet et al. 2005; Hales et al. 2009). Preliminary findings from this study indicate that the area of secondary phloem and xylem influence root tensile strength and shear strength within the cross-section of a single root.

The higher tensile force and tensile strength of $C$. korshinskii and $A$. canescens roots relative to the other species ( $Z$. xanthoxylon, $N$. tangutorum and L. chinense) may be attributed to their higher cellulose and lignin content. The thick periderm and watery sap in root cells of $Z$. xanthoxylon, along with the relatively low bast fiber content in their secondary bast thin wall cells, results in roots with a smaller tensile force and tensile strength compared with $C$. korshinskii and A. canescens. The secondary bast and secondary xylem of $N$. tangutorum and L. chinense also take up a smaller proportion of their roots' cross section. As they have limited mechanical strength components such as cellulose and lignin, these roots have lower tensile strength and shear strength. The primary factors which impact on single root tensile force and shear force are root xylogen percentage, root bast fiber percentage, root periderm lignification and rate of periderm lignification.

The root density, single root tensile and shear strength have an obvious influence on rooted soil strength of hillslopes. The shrubs analyzed in this study have significant tap and lateral roots, which spread both vertically and horizontally underground. Stokes et al. (1996) show that the most effective root branching models with which to enhance soil stability have large quantities of roots some depth from the ground surface. For some plants, roots may spread laterally over a distance that is several times greater than the plant height (Greenway 1987). Shrubs analysed in this study had root lengths from 1-5 m, which is 2-4 times plant height. Their root width extends extend over 0.5-4 m, with considerable lateral spread of roots at a depth of $0.2-1.5 \mathrm{~m}$. These plants are very effective at reinforcing and anchoring soil. These affects are closely related to root number, root diameter, root shape (architecture), root strength, and root-soil interaction (Wu et al. 1979; Stokes et al. 1996; Dupuy et al. 2007; Mickovski et al. 2007; Reubens et al. 2007). Indeed, studies show that structure-related root factors such as root density (RD), root length density (RLD), root area ratio (RAR), number of roots, maximum root depth and branching pattern are likely to exert a greater impact upon hillslope stability than factors such as 
root tensile strength (Reubens et al. 2007; Genet et al. 2005; Fattet et al. 2011; Mao et al. 2012; PollenBankhead et al. 2009).

Findings from this study indicate that $A$. canescens and $C$. korshinskii are much more effective shrubs with which to increase rooted soil shear strength compared to $Z$. xanthoxylon, $N$. tangutorum and $L$. chinense. These shrubs are well adapted to steep, bare, dry hillslopes on loess. Their long, well-spread roots and stem/branch structures promote greater retention of both water and soil on hillslopes, while their root tensile strength enhances resistance to shear, limiting prospects for shallow rotational landslips (Hubble et al. 2010).

Shallow landslide activity is one of many erosion mechanisms that affect loess hillslopes of northeastern Qinghai Province. For example, water erosion is widespread over vast areas in these steep, highly dissected and extensively gullied terrains (see Figure 2). An integrative approach to vegetation management on hillslopes is required to enhance hillslope stability in this area. A schematic conceptualization of complementary vegetative strategies is shown in Figure 12. This figure shows how herbaceous species with shorter, superficial roots can be used to maximize ground cover and associated interception, minimizing impacts of rainsplash and slowing runoff (and associated wash effects). These species can be used alongside selected shrubs that increase soil strength and reduce the likelihood of shallow landslides (with slip planes less than $2 \mathrm{~m}$ deep). Importantly, use of these vegetative strategies is not restricted to the lower, wetter parts of hillslopes, as these species are well adapted to high steep hillslopes - the areas where protection against soil erosion, shallow landslides and debris flows is most required (cf., Wang et al. 1998; Zhou et al. 2003; Guo et al. 2004; Li et al. 2007). Although plants need to be watered in their first growth year, by the second growth year their relatively longer roots ensure that they are able to extract water from depth, sustaining their growth. Future research is required to appraise the effectiveness of targeted vegetation management strategies.

\section{Conclusion}

Roots of five native shrubs markedly increase cohesion forces in soil, which in turn enhances the

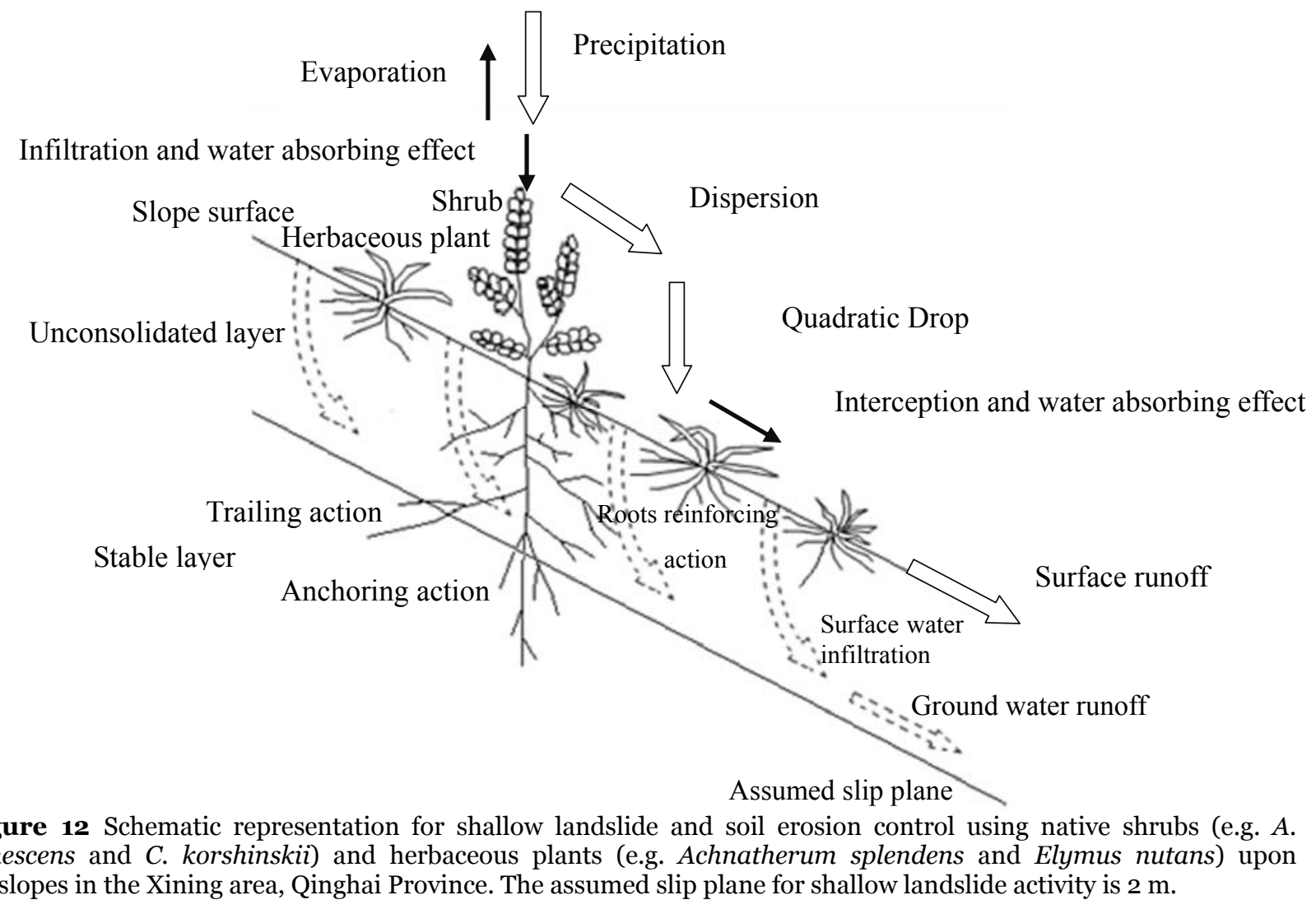


soil shear strength of hillslopes. These properties are directly affected by the anatomical structure of roots, especially the percentage of phloem fibers and wood fibers, and the degree and rate of periderm lignification. This affects single tensile resistance, shear resistance and ability to resist deformation. Compared with soils without roots, measured increases in amplitude of cohesion forces for root-soil composites of $A$. canescens, $C$. korshinskii, Z. xanthoxylon, $N$. tangutorum and $L$. chinense were $75.9,75.1,36.2,24.6$ and $17.0 \%$ respectively. Results of this exploratory analysis provide an important platform for hypothesis formulation to assess the effectiveness of vegetative strategies in reducing shallow landslide activity. Based upon findings of this study, it is suggested that $A$. canescens and $C$. korshinskii, along with herbaceous ground cover, is likely to provide an effective vegetative mechanism with which to enhance erosion control and reduce shallow landslides in this area.

\section{Acknowledgements}

The project was financially supported by the National Natural Science Foundation of China
(Grant No. 41162010), Excellent Talents in University of New Century by Ministry of Education of the People's Republic of China (Grant No. NCET04-G983), and International Science \& Technology Cooperation Program of China (Grant No. 2011DFG93160). The award of a China Scholarship Council (CSC) Visiting Scholar grant to Hu Xiasong supported the development of this paper at The University of Auckland. Gary Brierley was supported as a Distinguished Visiting Professor at the Chinese Academy of Sciences. This work was completed as part of the Three Brothers Project, in which researchers at the University of Auckland assist colleagues at Tsinghua University in supporting developments at Qinghai University. Support for this collaboration through MOST grants is gratefully acknowledged. The authors also extend their thanks to various colleagues at Qinghai University: Professors Sheng Hai-yan, Duan Xiao-ming, and Wang Liu-ying, Associate Professors Li Ji-hua, Zhang Xing-ling, Zhang Ying, Ni San-chuan, and, Lecturer Liang Tong, graduate students Lu Hai-jing, Li Hua-tan and undergraduate students Song Ningli and Liang Ying-ming. We thank Alan Cheung, Auckland University, for assistance in producing the figures. Substantive comments by two anonymous reviewers greatly enhanced this paper.

\section{References}

Burroughs ER Jr, Thomas BR (1977) Declining root strength in Douglas Fir after felling as a factor in slope stability. Research Paper INT-190, Intermountain Forest and Range Experiment Station, USDA, p 27.

Burylo M, Hudek C, Rey F (2011) Soil reinforcement by the roots of six dominant species on eroded mountainous manly slopes (Southern Alps, France). Catena 84:70-78. DOI: 10.1016/j.catena.2010.09.007

Chen CF, Liu HX, Li YP (2007) Study on grass roots-reinforced soil by laboratory triaxial test. Rock and Soil Mechanics 28(10): 2041-2045. (In Chinese) DOI: 10.3969/j.issn.10007598.2007.10.006.

Commandeur PR, Pyles MR (1991) Modulus of elasticity and tensile strength of Douglas Fir roots. Canadian Journal of Forest Research 21: 48-52. DOI:10.1139/x91-007.

De Baets S, Poesen J, Reubens B et al. (2008) Root tensile strength and root distribution of typical Mediterranean plant species and their contribution to soil strength. Developments in Plant and Soil 305: 207-226. DOI: 10.1007/s11104-0089553-0.

De Baets S, Poesen J, Reubens B et al. (2009) Methodological framework to select plant species for controlling rill and gully erosion: application to a Mediterranean ecosystem. Earth Surface Processes and Landforms 34: 1374-1392. DOI: 10.1002/esp.1826.

Dupuy L, Fourcaud T, Stokes A (2007) A numerical investigation into the influence of soil type and root architecture on tree anchorage. Developments in Plant and Soil 103: 175-189. DOI: 10.1007/978-1-4020-5593-5-17.

Ekanayake JC, Phillips CJ (1999) A method for stability analysis of vegetated hillslopes: an energy approach. Canadian Geotechnical Journal 36(6): 1172-1184. DOI: 10.1139/t99-o6o.

Fan CC, Chen YW (2010) The effect of root architecture on the shearing resistance of root-permeated soils. Ecological Engineering 36: 813-826. DOI: 10.1016/j.ecoleng.2010.03. 003.

Fan CC (2012) A displacement-based model for estimating the shear resistance of root-permeated soil. Plant Soil 355: 103119. DOI: $10.1007 / \mathrm{s} 11104-011-1084-4$.

Fattet M, Fu Y, Ghestem M et al. (2011) Efforts of vegetation type on soil resistance to erosion: Relationship between aggregate stability and shear strength. Catena 87: 60-69. DOI: 10.1016/j.catena. 2011.05.006

Genet M, Stokes A, Salin F et al. (2005) The influence of cellulose content on tensile strength in tree roots. Plant and Soil 278: 1-9. DOI: 10.1007/s11104-005-8768-6.

Gray DH, Sotir RB (1996) Biotechnical and Soil Bioengineering Slope Stabilization: A Practical Guide for Erosion Control. Wiley and Sons, Chichester.

Greenway DR (1987) Vegetation and slope stability. In: Anderson MG, Richards KS, (eds), Slope stability: Geotechnical Engineering and Geomorphology. Wiley and 
Sons, Chichester, pp 187-230.

Greenwood JR, Norris JE, Wint J (2004) Assessing the contribution of vegetation to slope stability. Proceedings of the ICE - Geotechnical Engineering 157(4): 199-207. DOI: 10.1680/geng. 157.4.199.51832

Guo HR, Lu XL, Liao ZW (2004) Ecological restoration method for rock slopes in Hong Kong. Pratacultural Science 21(9): 8386. (In Chinese)

Guo WJ, Huang GB, Wang FE et al. (2006) Study on constitutive relation of soil-root composite. Journal of China Agricultural University 11(2): 35-38. (In Chinese)

Hathaway RL, Penny D (1975) Root strength in some Populus and Salix clones. New Zealand Journal of Botany 13: 333-344.

$\mathrm{Hu}$ XS, Li GR, Zhu HL et al. (2009) Research on interaction between vegetation root and soil for protection and its mechanical effect in cold and arid environments. Chinese Journal of Rock Mechanics and Engineering 28(3): 613-620. (In Chinese)

Hu XS, Mao XQ, Zhu HL et al. (2011) Slope protection with vegetation on Qinghai-Tibet Plateau. Beijing: Geological Publishing House. (In Chinese)

Hales TC, Ford CR, Hwang T et al. (2009) Topographic and ecologic controls on root reinforcement. Journal of Geophysical Research 114: Fo3013. DOI: 10.1029/2008JF 001168.

Hubble TCT, Docker BB, Rutherfurd ID (2010) The role of riparian trees in maintaining riverbank stability: a review of Australian experience and practice. Ecological Engineering 36(3): 292-304. DOI: 10.1016/j.ecoleng.2009.04.006.

Ji J, Kokutse N, Genet M et al. (2012) Effect of spatial variation of tree root characteristics on slope stability. A case study on Black Locust (Robinia pseudoacacia) and Arborvitae (Platycladus orientalis) stands on the Loess Plateau, China. Catena 92: 139-154. DOI: doi:10.1016/j.catena.2011.12.008.

Li GR, Mao XQ, Ni SC et al. (2007) Brief analysis of the effect of slope protection by shrub-grass vegetation. Pratacultual Science 24(6): 86-89. (In Chinese)

Li RJ, Wang WQ, Liu DJ (2006) The comprehensive management of soil erosion in suburb's watershed of Xining City. Research of Soil and Water Conservation 13(4): 158-161. (In Chinese)

Li SC, Sun HL, Yang ZR et al. (2005) Interactional mechanical characteristics of rock-substrate-root system. Chinese Journal of Rock Mechanics and Engineering 24(8): 1407-1410. (In Chinese)

Li ZL (1978) Plant flaking technology, Beijing: Science Press. (In Chinese)

Liu GB, Jiang DS, Zhu XM (1996) Study on grasses root biomechanics in loess plateau. Journal of Soil and Water Conservation 2(3): 21-28. (In Chinese).

Liu XP, Chen LH, Song WF (2006) Study on the shear strength of forest root-loess composite. Journal of Beijing Forestry University 28(5): 67-72.

Liu Y (2003) Study of present status and measurements for soil erosion control as well as ecological environmental protection of Qinghai Province. Qinghai Science and Technology (1): 4-7. (In Chinese)

Loades KW, Bengough AG, Bransby MF et al. (2010) Planting density influence on fibrous root reinforcement of soil. Ecological Engineering 36: 276-284. DOI: 10.1016/j.ecoleng. 2009.02.005

Mattia C, Bischetti GB, Gentile F (2005) Biotechnical characteristics of root systems of typical Mediterranean species. Plant and Soil 278: 23-32. DOI: 10.1007/s11104-0057930-5.

Mickovski SB, Bengough AG, Bransby MF et al. (2007) Material stiffness, branching pattern and soil matric potential affect the pullout resistance of model root systems. European Journal of Soil Science 58: 1471-1481. DOI: 10.1111/j.13652389.2007.00953.x.

Mitsch WJ, Jorgensen SE (2003) Ecological engineering: a field whose time has come. Ecological Engineering 20(5): 363-377.
DOI: 10.1016/j.ecoleng.2003.05.001.

Mao Z, Laurent SA, Genet M et al. (2012) Engineering ecological protection against landslides in diverse mountain forests: Choosing cohesion models. Ecological Engineering 45: 55-69. DOI: 10.1016/j.ecoleng.2011.03.026.

Mao Z, Jourdan C, Bonis ML et al. (2013) Modelling root demography in heterogeneous mountain forests and applications for slope stability analysis. Plant Soil 363: 357382. DOI: $10.1007 / \mathrm{s} 11104-012-1324-2$.

Nilaweera NS, Nutalaya P (1999) Role of tree roots in slope stabilisation. Bulletin of Engineering Geology and the Environment 57: 337-342. DOI: 10.1007/s100640050056.

Norris JE (2005) Root reinforcement by hawthorn and oak roots on a highway cut slope in Southern England. Plant and Soil 278: 43-53. DOI: 10.1007/s11104-005-1301-0.

Odum HT, Odum B (2003) Concepts and methods of ecological engineering. Ecological Engineering 20(5): 339-361. DOI: 10.1016/j.ecoleng.2003.08.008.

Operstein V, Frydman S (2000) The influence of vegetation on soil strength. Ground Improvement 4: 81-89. DOI: 10.1680/ grim.2000.4.2.81.

Pollen-Bankhead N, Simon A (2009) Enhanced application of root-reinforcement algorithms for bank-stability modeling. Earth Surface Processes and Landforms 34: 471-480. DOI: 10.1061/40976(316)290

Pollen-Bankhead N, Simon A (2010) Hydrologic and hydraulic effects of riparian root networks on streambank stability: Is mechanical root-reinforcement the whole story? Geomorphology 116: 353-362. DOI: 10.5194/hess-15-16152011.

Ren YS (2004) Geological hazard and prevention measures in Xining City. Qinghai Soil and Economic Strategy 3: 31-33. (In Chinese).

Reubens B, Poesen J, Danjon F et al. (2007) The role of fine and coarse roots in shallow slopes stability and soil erosion control with a focus on root system architecture: a review. Trees 21: 385-402. DOI: 10.1001/s00468-007-0132-4.

Schiechtl MH (1980) Bioengineering for Land Reclamation and Conservation. University of Alberta Press, Edmonton. Alberta, p 404.

Stokes A, Ball J, Fitter AH et al. (1996) An experimental investigation of the resistance of model root systems to uprooting. Annals of Botany 78: 415-421. DOI: DOI: 10.1006/anbo.1996.0137

Thomas RE, Pollen-Bankhead N (2010) Modeling rootreinforcement with a fiber-bundle model and Monte Carlo simulation. Ecological Engineering 36: 47-61. DOI: 10.1016/ j.ecoleng.2009.09.008.

Thornes JB (1990) Vegetation and Erosion, Processes and Environments, Wiley and Sons, Chichester.

Turmanina V (1965) On the strength of tree roots. Bulletin of the Moscow Society of Naturalists, Biological Section 70:3645 (in Russian with English summary).

Waldron LJ (1977) The shear resistance of root-permeated homogenous and stratified soil. Soil Science Society of America Journal 41: 843-849.

Waldron LJ, Dakessian S (1981) Soil reinforcement by roots: Calculation of increased soil shear resistance from root properties. Soil Science 132(6): 427-435.

Wang KJ, Lee CF (1998) Brief mechanical analysis of bioengineering techniques for slope protection. Chinese Journal of Rock Mechanics and Engineering 17(6): 687-691. (In Chinese)

Wang Q, Xin WR, Liu TZ et al. (2003) Study on ecological environmental construction and water resources protection of Qinghai Province. Qinghai Science and Technology 1: 8-12. (In Chinese).

Wen ZX (1999) Urban disaster and effects of grassland and disaster reducing in Xining City. Journal of Qinghai Normal University (Natural Science) 1: 56-59. (In Chinese)

Wu TH (1976) Investigation of landslides on Prince of Wales Island, Alaska. Ohio State Univ., Dept. of Civil Eng., Geotech. 
Eng. Rpt. N5, p 93.

Wu TH, McKinnell WP, Swantson DN (1979) Strength of tree roots and landslides on Prince of Wales Island, Alaska, Canadian Geotechnical Journal 16: 19-33. DOI: 10.1139/t79003 .

Wu TH, Watson A (1998) In situ shear tests of soil blocks with roots. Canadian Geotechnical Journal 35(4): 579-590. DOI: 10.1139/t98-e027.

Xiao DS (2004) Theory of improving slope shear strength by vegetation. Basis of Foundation 1(2): 63-65. (In Chinese)

Xie WL, Wang JD, Wang YL (2004) Triaxial tests study on deform and strength characteristics of reinforced loess. Advance in Earth Sciences 19 (Suppl.): 333-339. (In Chinese)

Yang P, Xiang ZH, Hu XS, et al. (2009) Limit Load of Soil-Root Composites. CMC-Computers, Materials \& Continua 10(2): 117-137.

Yang YB, Shi B (2002) The method of vegetation for slope protection in slope treatment. Hydrological Geology and Engineering Geology (4): 41-44. (In Chinese)

Yang YC, Mo YJ, Wang ZF et al. (1996) Experimental study on anti-water erosion and shear strength of soil-root composite. Journal of China Agricultural University 1(2): 31-38. (In Chinese)

Zhang GQ, Chai NY, Zhao HF (2007) Actual conditions of soil and water erosion, ecology and control measure in the drainage area of Huangshui River. Journal of Northwest Forestry University 22(4): 70-72. (In Chinese)

Zhao CC, Ding X, Xin WR et al. (2008) Analysis of Factors of
Soil Erosion and Some Ways of Rehabilitation in Huangshui River of Qinghai Province. Research of Soil and Water Conservation 15(6): 200-202. (In Chinese)

Zhao DL (1994) Collapses and landslides and their control in mountain region of Xining City. Qinghai Environment 4(1): 29-31. (In Chinese)

Zhao LB, Zhang BG (2007) Experimental study on root biomechanics and relevant factors of Medicago sativa and Digitaria sanguinalis. Transactions of the Chinese Society of Agricultural Engineering 23(9): 7-12. (In Chinese)

Zhou DP, Zhang JY (2003) Bio-geotechnical technology of vegetation. Beijing: China Communications Press. (In Chinese)

Zhu HL, Hu XS, Mao XQ et al. (2008) Study on mechanical characteristics of shrub roots for slope protection in loess area of Tibetan plateau. Chinese Journal of Rock Mechanics and Engineering, 27(Supp. 2): 3445-3452. (In Chinese)

Zhu HL, Hu XS, Mao XQ et al. (2009) Relationship between mechanical characteristics and anatomical structures of slope protection plant root. Transactions of the CSAE 25(5): 40-44. (In Chinese)

Zhu QK, Chen LH, Zhang DS et al. (2002) Mechanical of soilreinforcement by roots in forest ecological systems in Gongga Mountain. Journal of Beijing Forestry University 24(2): 64-67. (In Chinese)

Ziemer RR (1981) Roots and the stability of forested slopes. In: Erosion and sediment transport in Pacific Rim steeplands. International Associated Hydrological Science 132: 343-361. 